\title{
Article \\ Influence of Earthquakes on Landslide Susceptibility in a Seismic Prone Catchment in Central Asia
}

\author{
Fengqing Li ${ }^{1, * \mathbb{D}}$, Isakbek Torgoev ${ }^{2} \mathbb{D}$, Damir Zaredinov ${ }^{3}$, Marina Li $^{3}$, Bekhzod Talipov ${ }^{4}$, Anna Belousova ${ }^{5}$, \\ Christian Kunze ${ }^{6,+}$ and Petra Schneider $1,+\mathbb{D}$
}

Citation: Li, F.; Torgoev, I.;

Zaredinov, D.; Li, M.; Talipov, B.;

Belousova, A.; Kunze, C.; Schneider, P.

Influence of Earthquakes on

Landslide Susceptibility in a Seismic

Prone Catchment in Central Asia.

Appl. Sci. 2021, 11, 3768. https://

doi.org/10.3390/app11093768

Academic Editor: Hyuck-Jin Park

Received: 31 March 2021

Accepted: 20 April 2021

Published: 22 April 2021

Publisher's Note: MDPI stays neutral with regard to jurisdictional claims in published maps and institutional affiliations.

Copyright: (c) 2021 by the authors. Licensee MDPI, Basel, Switzerland. This article is an open access article distributed under the terms and conditions of the Creative Commons Attribution (CC BY) license (https:/ / creativecommons.org/licenses/by/ $4.0 /)$.
1 Department of Water, Environment, Construction and Safety, Magdeburg-Stendal University of Applied Sciences, Breitscheidstr. 2, 39114 Magdeburg, Germany; Petra.Schneider@h2.de

2 Scientific Engineering Centre "GEOPRIBOR" of the National Academy of Sciences of the Kyrgyz Republic, Mederova Str. 98, Bishkek 720052, Kyrgyzstan; isakbektor@mail.ru

3 The Ministry of Health of the Republic of Uzbekistan, 12 Navoi Street, Tashkent 100011, Uzbekistan; zda_medic@mail.ru (D.Z.); marina.li@uzliti-en.com (M.L.)

4 Department of Radiation and Nuclear Safety of the State Committee on Industrial Safety 27, A. Navoiy Str., Tashkent 100011, Uzbekistan; btalipov77@gmail.com

5 C\&E Consulting und Engineering GmbH, Jagdschänkenstr. 52, 09117 Chemnitz, Germany; anna.belousova@cue.gmbh

6 IAF-Radioökologie GmbH, Wilhelm-Rönsch-Straße 9, 01454 Radeberg, Germany; Kunze@iaf-dresden.de

* Correspondence: Fengqing.Li@h2.de; Tel.: +49-391-8864736

$+\quad$ The last two authors contributed equally to this work.

\begin{abstract}
Central Asia is one of the most challenged places, prone to suffering from various natural hazards, where seismically triggered landslides have caused severe secondary losses. Research on this problem is especially important in the cross-border Mailuu-Suu catchment in Kyrgyzstan, since it is burdened by radioactive legacy sites and frequently affected by earthquakes and landslides. To identify the landslide-prone areas and to quantify the volume of landslide (VOL), Scoops3D was selected to evaluate the slope stability throughout a digital landscape in the Mailuu-Suu catchment. By performing the limit equilibrium analysis, both of landslide susceptibility index (LSI) and VOL were estimated under five earthquake scenarios. The results show that the upstream areas were more seismically vulnerable than the downstream areas. The susceptibility level rose significantly with the increase in earthquake strength, whereas the VOL was significantly higher under the extreme earthquake scenario than under the other four scenarios. After splitting the environmental variables into sub-classes, the spatial variations of LSI and VOL became more clear: the LSI reduced with the increase in elevation, slope, annual precipitation, and distances to faults, roads, and streams, whereas the highest VOL was observed in the areas with moderate elevations, high precipitation, grasslands, and mosaic vegetation. The relative importance analysis indicated that the explanatory power reduced with the increase in earthquake level and it was significant higher for LSI than for VOL. Among nine environmental variables, the distance to faults, annual precipitation, slope, and elevation were identified as important triggers of landslides. By a simultaneous assessment of both LSI and VOL and the identification of important triggers, the proposed modelling approaches can support local decision-makers and householders to identify landslide-prone areas, further design proper landslide hazard and risk management plans and, consequently, contribute to the resolution of transboundary pollution conflicts.
\end{abstract}

Keywords: earthquake impacts; volume estimation; Scoops3D; limit equilibrium method; radioactive contamination; Tien Shan Mountains

\section{Introduction}

As one of the greatest natural hazards in the world, landslides occur frequently due to the downslope movement of rock, debris, or soil, and have caused huge property damages, personal injuries, and even loss of human lives [1,2]. In total, landslides account for 
about $9 \%$ of the past world's disasters [3], and the damages of landslides to society and environment are expected to increase in the future [2,4]. The factors that can potentially trigger landslides are numerous and interdependent, comprising both natural events (e.g., earthquakes, droughts, intensive rainfalls, rapid snow melting, volcanic activities, groundwater pressure, geomorphological processes, and wildfire) [5-7] and anthropogenic activities (e.g., deforestation, agricultural cultivation, quarries, mines, and infrastructural development) [8-10].

To minimise the loss of lives and damage to properties, the landslide susceptibility assessment is usually the first step $[11,12]$ and has been playing an important role in the past, for instance, for safe and economic planning, especially for the selection of safe localities of infrastructure $[11,13]$. By showing the probability of landslides in an area, a landslide susceptibility map can be used to determine spaces with potential landslide risks $[8,14]$. However, in engineering practice, the potential volume of landslide (VOL), which refers to the volume of material between the ground surface and the potential failure surface [15], is more frequently required because (1) it is the best way to indicate the magnitude and the realistic size of each individual landslide [16-18]; (2) with the knowledge of volume, engineers can develop precise mitigation plans and relevant budget measures $[19,20]$; and (3) it is a fundamental indicator to estimate secondary hazards (e.g., formation and break of landslide dams, amount and duration of debris flows, isolated districts due to traffic disruption, and long-term degradation of mountainous vegetation) [21-23]. However, due to the complicated process of volume simulation and the lack of soil information related to potential failure surface, the majority of previous studies related to landslides focuses on either landslide susceptibility maps or the volume estimation of the occurred landslides in the past $[8,16]$, and only very few studies have attempted to predict the potential VOL [15].

In total, five types of methods have been developed for the volume estimation: field surveys (e.g., trenching and drilling boreholes for direct measurements of the position and geometry of geologic discontinuities), geometrical estimation (e.g., ellipsoids based on surface displacement and morphology), empirical modelling (e.g., the California and USGS methods for the estimation of landslide displacements), multi-temporal DEM (digital elevation model) analysis (e.g., the differed-time analysis of past movements and the records of recent slope movements), and physically-based modelling [1,8,16,24]. Among them, the physically-based modelling has been recently widely used [20]. By integrating terrain data (e.g., DEM), soil parameters (e.g., layer depth, cohesion, angle of internal friction, and specific gravity), and hydrological parameters (e.g., pore water pressure), the physically-based models can mimic the underground situation. Based on the mimicked underground situations, the physically-based models can simulate the unstable slopes and further calculate the slope stabilities (i.e., landslide susceptibility index or LSI) and VOL $[15,25]$. Currently, two types of principles have been adopted in the physically-based models for the slope stability analysis: limit equilibrium method (LEM) and finite element method (FEM) [26,27]. LEM predefines the failure surfaces for slopes and analyses the stabilities of those predefined failure surfaces [28,29]. In contrast to LEM, FEM does not predefine failure surfaces [26,27]. It should be noted that most of the physicallybased models adopt LEM to carry out the slope stability analysis [15,29]. Applications, such as CLARA [30], 3D-SLOPE [31], the script from Marchesini et al. [18], r.rotstab [32], Scoops3D [33], and OpenLISEM [34], were developed for this purpose. In this study, Scoops3D was selected because this model is designed to simulate the LSI and VOL resulting from a series of plausible scenarios, such as the effects of different intensities of earthquakes [33].

The development of land sliding is one of the most complex geomorphological processes, and has potential relationships with the topographic variables (e.g., elevation, slope, and aspect), land cover, soil type, precipitation pattern, and possibly also proximity variables (e.g., distance to faults, roads, and streams) [19,35-37]. Topography is one of the critical variables in the landslide phenomenon: elevation determines the temperature gradient and the distribution of vegetation [38,39]; slope and aspect are related to the 
exposure to sunlight and drying wind, and they can influence the soil moisture and the distribution of vegetation [13]. Slope stability is also strongly influenced by land cover; for instance, due to a strong rooting system, forest trees can enhance the slope stability [40,41]. Soil characteristics are another crucial controlling variable for the occurrence of landslides, because each soil type has its own susceptibility rate [42]. Intensive rainfall events can also increase the probability of landslides in mountainous areas $[35,43,44]$. Moreover, the proximity variables are related to lineament, anthropogenic activities, and erosion processes $[36,37,45]$. However, the relative importance of these environmental variables is different and varies from catchment to catchment. The determination of the most important variables can allow the limited human power and budget to be investigated in terms of maintenance and improvement of the most important variables and their conditions, and it can also assist the engineering plan by avoiding unstable areas (e.g., in the proximity of faults or specific topographic areas).

As a result of landslides, developing countries are facing more devastating consequences due to poor infrastructure and the lack of hazard management systems [13], for example, Kyrgyzstan and the surrounding neighbours within the Tien Shan Mountains $[46,47]$. The Tien Shan Mountains are frequently affected by seismic activities (e.g., earthquakes) [48], and several strong earthquakes struck this area and its surroundings during the last century, such as the Kemin earthquake in 1911 with a magnitude of 7.7 (or M 7.7), the Chatkal earthquake in 1946 (M 7.6), the Khait earthquake in 1949 (M 7.4) and the Suusamyr earthquake in 1992 (M 7.3) [49]. One hotspot of earthquakes and landslides in the Tien Shan area is the Ferghana Valley, where the studied Mailuu-Suu catchment (Figure 1c) is located [50,51]. In the Kyrgyz part of the Ferghana Valley, the first recorded massive activation of landslides occurred in 1954 and was followed by other events in 1958, 1969, 1979, 1988, 1993-1994, 1998, 2003-2005, and 2017 [50,52]. The studied Mailuu-Suu catchment (Figure 1 ) and its neighbouring areas are also frequently affected by earthquakes [48,50]. For example, the recorded strongest earthquake (M 6.6 with a depth of $49.5 \mathrm{~km}$ ) struck the Jalal-Abad region (30 km far from the Mailuu-Suu catchment) on 19 August 1992, and it cost the lives of 54 people, directly affected 86,800 people, and resulted in an economic loss of approximately USD 130 million [53].

Besides the effects of earthquakes and landslides, the Mailuu-Suu catchment and the nearby regions (e.g., Min-Kush and Shekaftar in the Kyrgyz Republic, Charkesar and Yangiabad in the Republic of Uzbekistan, as well as Degmay and Istiklol in the Republic of Tajikistan) are exposed to another important environmental problem, namely a high risk of radioactive contamination resulting from a large portion of radioactive wastes (e.g., tailings ponds and dumps with radionuclides like Ra-226, Pb-210, Po-210, and U238) [50,54]. After 1995, the conventional mines were closed [55]. However, most of the tailing ponds and dumps were not properly rehabilitated and showed a quasi-continuous release of radioactive contamination into the local environment $[50,54]$. In case of the sudden destruction of the tailing ponds due to earthquake-induced landslides in the Mailuu-Suu catchment, both clean and radioactive polluted soils may be substantially expanded through the river networks and transported across the Kyrgyz-Uzbek border, adding a potential transboundary conflict to the existing political and environmental problems $[54,56]$.

To date, most studies related to landslide focused on the assessment of landscape stability and the development of LSI, but the evaluation of VOL has been largely ignored $[15,24]$. However, proper risk management plans and engineering practices can only be achieved by a simultaneous assessment of LSI and VOL. Central Asian countries, due to limited research budgets, despite being frequently struck by earthquake and burdened by radioactive legacy sites, are in particular need of research in this field. Therefore, this study aims to (1) identify the landslide prone areas in the Mailuu-Suu catchment, utilising maps of LSI and VOL under a series of earthquake scenarios from moderate to extreme and (2) examine the relationships between nine environmental variables and the spatial 
distributions of LSI and VOL, in order to determine the most important variables which should be considered as priorities in future risk management plans.

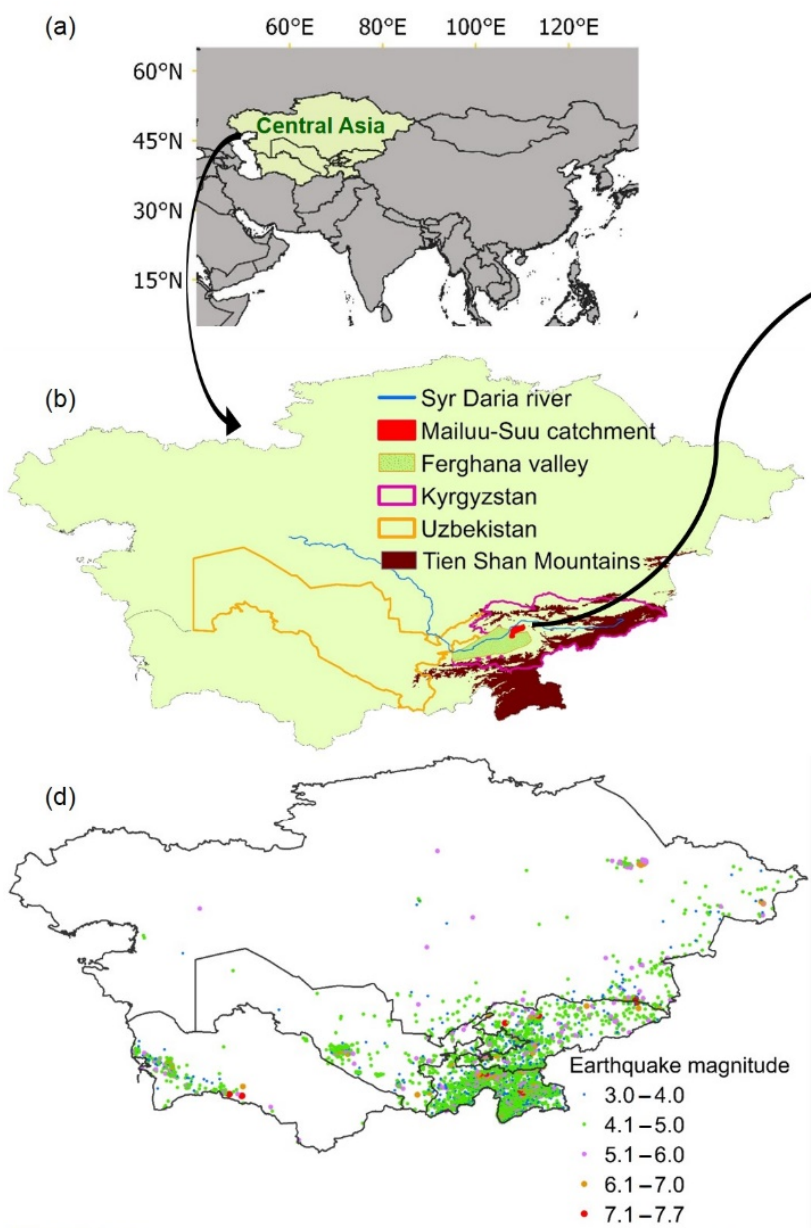

(c)
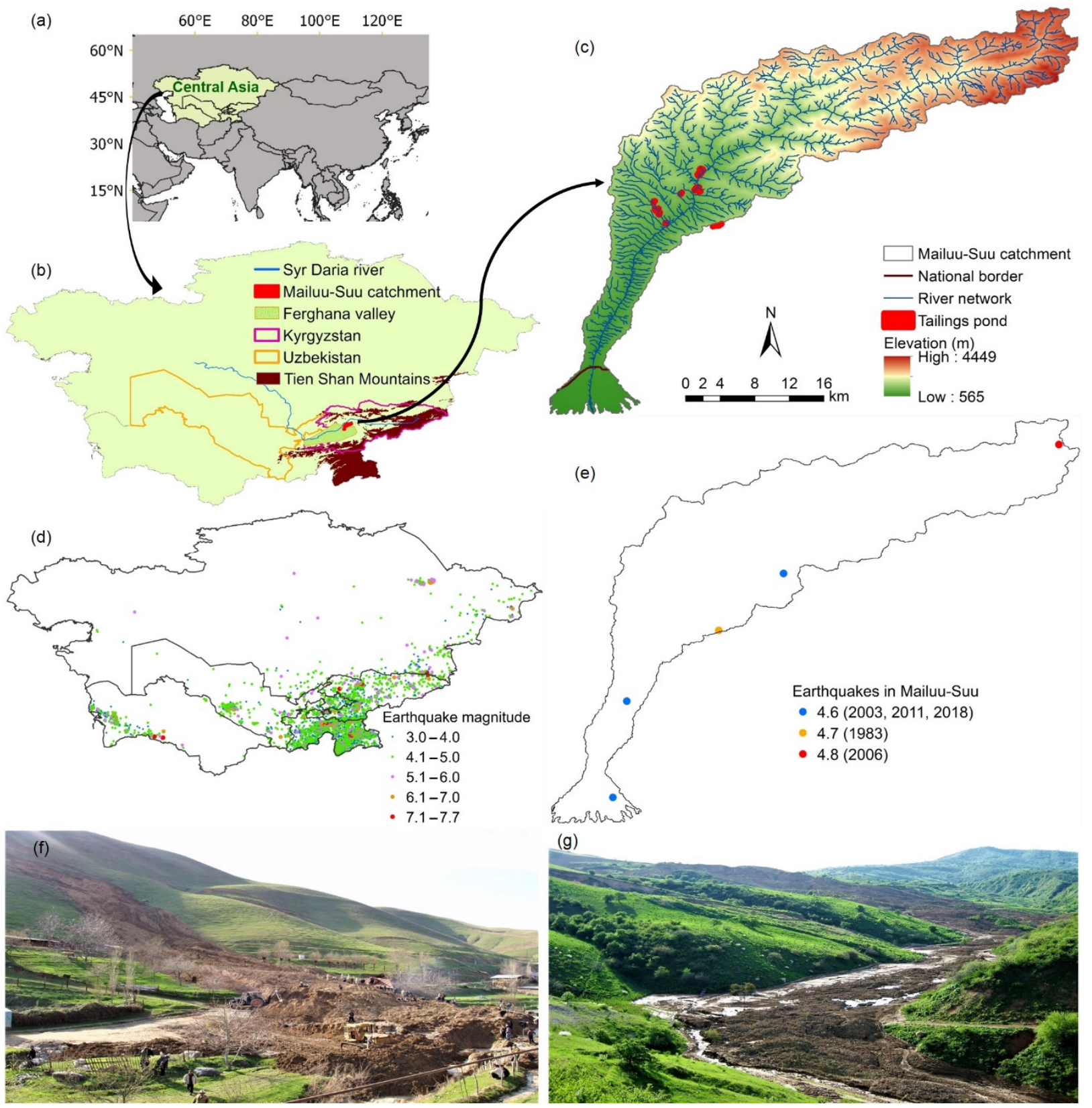

Figure 1. Maps of (a) the locality of Central Asia, (b) the important toponyms in the study area, (c) the distributions of tailings ponds and the elevation pattern of the Mailuu-Suu catchment, the localities of the recorded earthquake events in (d) Central Asia and (e) the Mailuu-Suu catchment between 1900 and 2020, and (f,g) the past landslide events in the Mailuu-Suu catchment.

\section{Materials and Methods}

\subsection{Study Area}

The study area of the Mailuu-Suu catchment lies in the north-eastern part of the Ferghana Valley in Central Asia. The Mailuu-Suu river feeds the Syr Daria river, which is the major source of irrigation water in the Ferghana Valley (Figure 1) [50]. The catchment is located at 600-4400 m.a.s.l. with a catchment area of $530 \mathrm{~km}^{2}$, and is characterized by semiarid climatic conditions [48]. This study area belongs to the tectonically and seismically 
active Tien Shan Mountains [48]. These mountains are an earthquake hotspot originating from the continent movements of India and Asia [48]. In total, 4933 earthquake events with a magnitude greater than 3.0 were observed in the Central Asian part of the Tien Shan Mountains during 1900 and 2020 (https:/ / earthquake.usgs.gov; accessed on 22 March 2021 Figure 1d). The maximum magnitude of 7.7 (or M 7.7) was recorded in the eastern part of Kazakhstan (latitude $=43.01^{\circ}$ and longitude $=78.53^{\circ}$ ) on 3 January 1911. Five earthquake events were recently recorded in the Mailuu-Suu catchment, namely in 1983 (M 4.7), 2003 (M 4.6), 2006 (M 4.8), 2011 (M 4.6), and 2018 (M 4.6) (Figure 1e). During the last 50 years, the catchment has experienced severe landslide disasters in the vicinity of numerous radioactive waste tailings ponds $[46,48]$. The probability of the damages of earthquake and landslide in this catchment is expected to increase in the future as a result of anthropogenic activities, such as deforestation, overgrazing, agricultural activities and development of infrastructure. Furthermore, the population growth will also provide more pressure on the fragile landscape and make the study area more vulnerable to landslide [46,48].

As a former uranium mining area [52,57], in and around the Mailuu-Suu town, uranium mining and milling activities started in 1946 and lasted until 1968 [48,54]. Most of the waste dumps and tailing ponds (Figure 1c) from mining were deposited in the moderate mountainous terrain and gently sloping alluvial areas [54,58]. Under the effect of earthquakes, the release of radioactive soils from the tailing ponds is highly likely to run into the river networks and further transport into the downstream areas, where agricultural activities and dense populations can be largely affected.

\subsection{Data Collection}

Data collection was performed as a part of the TRANSPOND (Transboundary Monitoring and Information System for Radioactive Contamination in the Event of Natural Hazards) project. The collected data included input data for the Scoops3D (i.e., DEM, soil parameters, and pore water pressure ratio) and nine environmental variables for the relationship analysis (i.e., elevation, slope, aspect, land cover, soil type, annual precipitation, distance to faults, roads, and streams). The collected input data were used to perform the simulation of Scoops3D under five earthquake scenarios (i.e., moderate, strong, severe, violent, and extreme). The limit equilibrium method was employed in order to predefine the potential failure surface and investigate the equilibrium state of the predefined failure surface. As the outputs of Scoops3D, two landslide metrics (i.e., LSI and VOL) were generated. These two landslide metrics and nine environmental variables were then used to perform the relationship analysis with the RandomForest program, in order to determine the relative importance of the environmental variables in structuring the spatial patterns of the landslide metrics. The scheme for the data process, modelling approaches, and the relationship analysis is shown in Figure 2.

The DEM data were obtained from the SRTM (shuttle radar topography mission) dataset (resolution: $30 \mathrm{~m}$; www.usgs.gov; accessed on 24 November 2020) and further downscaled into a resolution of $10 \mathrm{~m}$ using the bilinear resampling approach in the ArcGIS (geographic information system) software V10.7. This DEM raster data were then converted into the ASCII (American Standard Code for Information Interchange) grid format, as required by Scoops3D.

The soil parameters were obtained from the Scientific Engineering Centre "GEOPRIBOR" (SECG) in Kyrgyzstan. In this dataset, six soil layers were measured in situ in the Mailuu-Suu catchment. The measured parameters included layer depth, cohesion, angle of internal friction, and specific gravity. The averaged values were used to represent the overall conditions of soil properties in the Mailuu-Suu catchment, and they were $3.7 \mathrm{~m}$, $17.7 \mathrm{kPa}, 30.3^{\circ}$, and $19.7 \mathrm{kN} / \mathrm{m}^{3}$, respectively (Table 1 ). The detailed measurement method of the soil parameters is available in Torgoev and Li et al. [56,59]. 


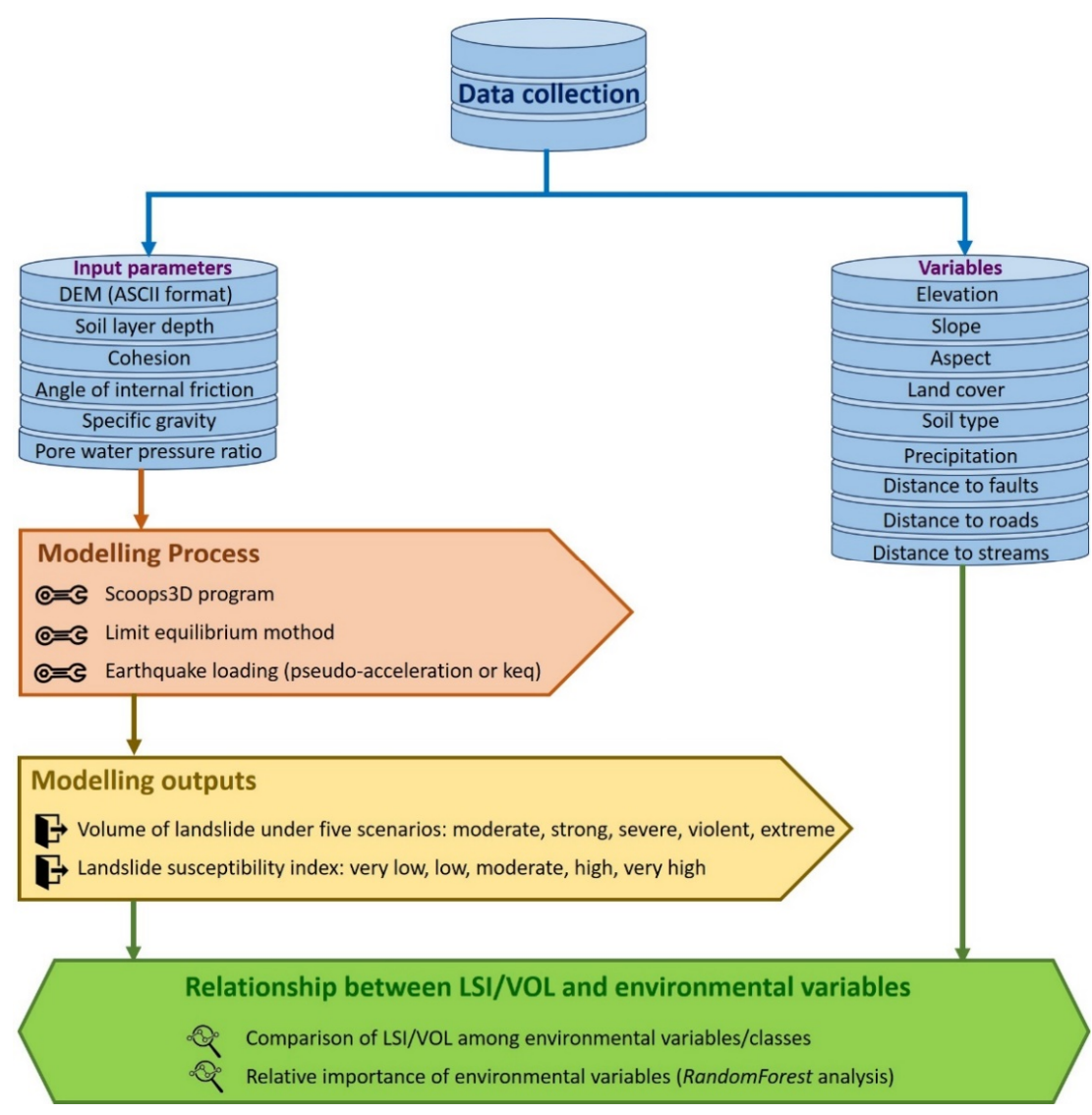

Figure 2. The scheme for the data process and modelling approaches. DEM refers to digital elevation model, ASCII refers to American Standard Code for Information Interchange, LSI refers to landslide susceptibility index, and VOL refers to volume of landslide.

Table 1. Input soil parameters for the simulations of Scoops3D in the Mailuu-Suu catchment (adapted from Li et al. [56]).

\begin{tabular}{|c|c|c|c|c|c|}
\hline Layer & $\begin{array}{l}\text { Depth } \\
\text { (m) }\end{array}$ & $\begin{array}{l}\text { Cohesion } \\
(\mathrm{kPa})\end{array}$ & $\begin{array}{l}\text { Angle of Internal } \\
\text { Friction }\left(^{\circ}\right)\end{array}$ & $\begin{array}{l}\text { Specific Gravity } \\
\left(\mathrm{kN} / \mathrm{m}^{3}\right)\end{array}$ & $\begin{array}{c}\boldsymbol{R}_{u} \\
\text { Coefficient }\end{array}$ \\
\hline L01 & 4.0 & 11.6 & 36.0 & 19.2 & 0.13 \\
\hline L02 & 5.2 & 11.3 & 32.3 & 19.2 & 0.10 \\
\hline L03 & 4.0 & 8.8 & 31.0 & 20.0 & 0.12 \\
\hline L04 & 2.0 & 40.0 & 23.0 & 19.1 & 0.26 \\
\hline L05 & 2.5 & - & - & 21.0 & 0.19 \\
\hline L06 & 4.3 & 16.7 & 29.0 & 19.6 & 0.12 \\
\hline Average & 3.7 & 17.7 & 30.3 & 19.7 & 0.15 \\
\hline
\end{tabular}

Scoops3D includes two triggering factors, namely the pore water pressure caused by groundwater [60] and the earthquake loading [12,61]. To reflect the effect of pore water pressure, the $R_{u}$ coefficient was employed. This value refers to the pore water pressure ratio and ranges between 0 and 1 . The calculation of the $R_{u}$ coefficient is based on Equation (1):

$$
R_{u}=\frac{u}{\gamma z}
$$

where $R_{u}$ is the pore water pressure ratio, $u$ is the pore water pressure, $\gamma$ is the specific gravity of the soil, and $z$ is the depth below ground.

For the specific gravity and depth, the above-mentioned soil parameters were used. According to the suggestion from SECG, the pore water pressure was defined as $10 \mathrm{kPa}$ 
based on the in situ measured values (ranged between 6.0 and $13.8 \mathrm{kPa}$ with an average of $10.0 \mathrm{kPa}$ ) [62]. In this sense, the value of $R_{u}$ coefficient could be calculated for each layer with an average value of 0.15 (Table 1 ).

To reflect the effect of the second triggering factor, the seismic loading by means of a specified horizontal pseudo-acceleration coefficient ( $k e q$, dimensionless and scaled as a fraction of gravity, g) was employed [33]. This specified coefficient is applied as a uniform horizontal force to represent the effects of peak ground acceleration from an earthquake [63,64]. The USGS (United States Geological Survey) developed a scale of the earthquake magnitude and the corresponding peak ground acceleration (Table 2). In this study, we applied this information and selected five typical earthquake scenarios, namely M 5.0 ( $k e q=0.092$, moderate), M 6.0 ( $\mathrm{keq}=0.18$, strong), M 7.0 ( $\mathrm{keq}=0.34$, severe), M 8.0 $(\mathrm{keq}=0.65$, violent), and M $9.0(\mathrm{keq}=1.24$, extreme $)$ (Table 2).

Table 2. Summary of the earthquake magnitude and the corresponding peak ground acceleration, frequency of occurrence, perceived shaking and potential damage (adapted from www.usgs.gov; accessed on 22 March 2021). The selected magnitudes and their accelerations were marked in bold and italic.

\begin{tabular}{|c|c|c|c|c|}
\hline Magnitude & Acceleration (g) & $\begin{array}{c}\text { Frequency of } \\
\text { Occurrence Per Year }\end{array}$ & $\begin{array}{l}\text { Perceived } \\
\text { Shaking }\end{array}$ & Potential Damage \\
\hline $1.0-1.9$ & $<0.0017$ & Several million & Not felt & None \\
\hline $2.0-3.9$ & $0.0017-0.039$ & 100,000 to 1 million & Weak & No damage or very rarely damage \\
\hline $4.0-4.9$ & $0.039-0.092$ & 10,000 to 15,000 & Light & Minor damage possible \\
\hline $5.0-5.9$ & $0.092-0.18$ & 1000 to 1500 & Moderate & $\begin{array}{l}\text { Severe damage to poorly constructed buildings. } \\
\text { Zero to slight damage to all other buildings. } \\
\text { Damage to a few well-built structures. }\end{array}$ \\
\hline $6.0-6.9$ & $0.18-0.34$ & 100 to 150 & Strong & $\begin{array}{l}\text { Earthquake-resistant structures survive with slight } \\
\text { to moderate damage. Poorly designed structures } \\
\text { receive moderate to severe damage. }\end{array}$ \\
\hline 7.0-7.9 & $0.34-0.65$ & 10 to 20 & Severe & $\begin{array}{l}\text { Damage to most buildings, partially or completely } \\
\text { collapse or severe damage. Well-designed } \\
\text { structures are likely to receive damage. }\end{array}$ \\
\hline $8.0-8.9$ & $0.65-1.24$ & About 1 & Violent & $\begin{array}{l}\text { Major damage to buildings, structures likely to be } \\
\text { destroyed. Moderate to heavy damage to sturdy or } \\
\text { earthquake-resistant buildings. }\end{array}$ \\
\hline $\begin{array}{l}9.0 \text { and } \\
\text { greater }\end{array}$ & $>1.24$ & 1 per 10 to 50 years & Extreme & $\begin{array}{c}\text { At or near total destruction-severe damage or } \\
\text { collapse to all buildings. }\end{array}$ \\
\hline
\end{tabular}

Landslide hazards are caused by a series of variables and their interactions, including both the internal geological conditions and external environmental conditions $[65,66]$. In this study, nine environmental variables were selected to perform the relationship analysis, including elevation, slope, aspect, land cover, soil type, annual precipitation, distance to faults, roads, and streams.

First, three topographic variables, including elevation, slope, and aspect, were extracted using the above-mentioned DEM with a spatial resolution of $10 \mathrm{~m}$ in ArcGIS. The values of elevation were the original values of DEM, whereas the values of slope and aspect were calculated using the slope-aspect function of ArcGIS. Elevation and slope were classified into four classes in order to compare the variations of LSI and VOL across the spatial scales: low (576-1000 m), moderate (1000-2000 m), high (2000-3000 m), and very high $(>3000 \mathrm{~m})$ for elevation; gentle $\left(0-10^{\circ}\right)$, moderate $\left(10-25^{\circ}\right)$, steep $\left(25-40^{\circ}\right)$, and very steep $\left(>40^{\circ}\right)$ for slope. Aspect was classified into eight classes: north (0-22.5 and 337.5-360), northeast (22.5-67.5), east (67.5-112.5), southeast (112.5-157.5), south (157-202.5), southwest (202.5-247.5), west (247.5-292.5), and northwest (292.5-337.5).

Second, the used land cover data were Globcover 2009 V2.3 from European Space Agency (http:/ / due.esrin.esa.int/page_globcover.php; accessed on 20 February 2021) with a resolution of $300 \mathrm{~m}$ [67]. In these data, 23 types of land cover are developed. Among them, 14 types are occurring in the Mailuu-Suu catchment. To simplify the analysis, eight 
classes were used (i.e., some types were merged into one type): forest (assigned to the value of 8 for the following analysis), mosaic vegetation (assigned value: 7), grassland (assigned value: 6), mosaic cropland/vegetation (assigned value: 5), cropland (assigned value: 4 ), sparse vegetation (assigned value: 3 ), water/snow (assigned value: 2 ), and bare areas (assigned value: 1 ).

Third, the soil data were extracted from the digital soil map of the world (https: //worldmap.harvard.edu; accessed on 20 February 2021). Five out of 106 soil types are found in the Mailuu-Suu catchment, and they are Lithosols Humic Cambisols (code: I-Bh-2c, assigned value: 5), Lithosols Chromic Cambisols Humic Cambisols (code: I-BcBh-c, assigned value: 4), Lithosols Chromic Cambisols (code: I-Bc-2c, assigned value: 3), Lithosols Calcic Xerosols (code: I-Xk-2c, assigned value: 2), and Calcic Xerosols (code: Xk4-2ab, assigned value: 1 ).

Fourth, the annual precipitation data were obtained from WorldClim V2.1 (www. worldclim.org; accessed on 20 February 2021) with a resolution of $1 \mathrm{~km} \mathrm{[68].} \mathrm{These} \mathrm{data}$ were further downscaled into $10 \mathrm{~m}$ using the bilinear resampling approach in the ArcGIS. In this study, the average value of the reference period (i.e., 1970-2000) was used as the annual precipitation. Based on the amount, the precipitation was classified into four classes: low (278-450 mm), moderate (450-600 mm), high (600-700 mm), and very high (>700 $\mathrm{mm})$.

Fifth, three proximity variables, including distance to faults, roads, and streams were selected. The localities of the faults were obtained from "Active Tectonics of the Northern Tien Shan" (http:/ / activetectonics.asu.edu/N_tien_shan/N_tien_shan_data.html; accessed on 20 February 2021). The roads were obtained from HOTOSM (Humanitarian OpenStreetMap, www.hotosm.org; accessed on 20 February 2021), and stream networks were generated using the DEM data and the hydrologic analysis of ArcGIS. The value of distance of a given point to the nearest line was calculated based on the Euclidean distance method in ArcGIS. The distance to faults was classified into four classes using the equal interval method: $0-5,5-10,10-15$, and $>15 \mathrm{~km}$. Similarly, the four classes of distance to roads were $0-1,1-2,2-3$, and $>3 \mathrm{~km}$, and the four classes of distance to streams were $0-0.1$, $0.1-0.2,0.2-0.3$, and $>0.3 \mathrm{~km}$.

\subsection{Scoops3D Model}

Scoops3D was developed by the USGS for evaluating slope stability throughout a digital landscape represented by a DEM [33]. Scoops3D applies the limit equilibrium method to analyse slope stability. This method predefines the potential failure surface and investigates the equilibrium state (the equilibrium of forces or moments) of the predefined failure surface. Assumptions of the limit equilibrium method are as follows: (1) the failure volume consists of rigid materials and slides along a single failure plane; (2) failure occurs simultaneously along the potential slip surface without progressive movement. The factor of safety $(F O S)$ is uniform everywhere along the predefined slip surfaces and one predefined slip surface has one single FoS; and (3) the deformation and strain of the potential failure volume, as well as dynamic loading are ignored [69]. The equilibrium state is expressed by a ratio, FoS, and can be calculated based on Equation (2):

$$
F o S=\frac{R}{T}
$$

where $F o S$ is the factor of safety for the predefined failure surface, $R$ is the upslope stabilising force, and $T$ is the downslope destabilising force.

Two major outputs of Scoops3D were LSI (or minimum FoS) and VOL. The LSI maps were then classified into five susceptibility groups, namely very unstable ( $F o S \leq 0.5)$, unstable (FoS: $0.5-1.0)$, moderate (FoS: $1.0-1.5)$, stable (FoS: $1.5-2.0)$, and very stable $(F o S \geq 2.0$ ). The VOL maps were also classified into five groups using the natural break method in ArcGIS: very low $\left(1.0 \times 10^{3}-2.0 \times 10^{8} \mathrm{~m}^{3}\right)$, low $\left(2.0 \times 10^{8}-4.0 \times 10^{8} \mathrm{~m}^{3}\right)$, moderate $\left(4.0 \times 10^{8}-6.0 \times 10^{8} \mathrm{~m}^{3}\right)$, high $\left(6.0 \times 10^{8}-8.0 \times 10^{8} \mathrm{~m}^{3}\right)$, and very high $\left(8.0 \times 10^{8}-1.0 \times 10^{9} \mathrm{~m}^{3}\right)$. 


\subsection{Statistical Analyses}

To account for variability and uncertainty of the simulated landslide metrics, 1000 random sites across the Mailuu-Suu catchment were created, and all analyses were performed based on these 1000 random sites. Random sites were selected using the "sp" package [70] in R 3.5.2 [71].

Analysis of variance (ANOVA) was performed to evaluate differences in LSI and VOL among the earthquake scenarios. Tukey's multiple comparison tests were then carried out where significant differences were detected $(\alpha=0.05)$. This analysis was performed using the "vegan" package [72] in R 3.5.2 [71].

As a non-parametric method, the random forest analysis was used to assess the relationship between a large number of potential predictor variables and the response variable $[73,74]$. In this study, this analysis was selected to assess the relationship between environmental variables and landslide metrics, and further determine the relative importance of environmental variables for the explanation of variations of landslide metrics. The analysis was conducted using the "randomForest" package [73] in R 3.5.2 [71].

\section{Results}

\subsection{Landslide Susceptibility Index and Volume of Landslide}

Maps of LSI and VOL were developed in the Mailuu-Suu catchment. The results showed that the upstream areas were more unstable than the downstream areas under the first four earthquake scenarios (namely moderate, strong, severe, and violent) (Figure 3a), whereas most areas were identified as very unstable (LSI $\leq 0.5)$ under the extreme earthquake scenario (Figure 3a). Under the moderate scenario, most downstream areas were stable or very stable, and with the increase in earthquake strength, the entire catchment became more unstable (Figure 3a). Such patterns were also observed by comparing the average values of LSI under the five earthquake scenarios (Figure 4). These average values were calculated to be $1.02 \pm 0.60$ (mean \pm standard deviation or SD), $0.81 \pm 0.38$, $0.57 \pm 0.23,0.33 \pm 0.15$, and $0.23 \pm 0.14$ under moderate, strong, severe, violent, and extreme earthquake scenarios, respectively (Figure 4). Each scenario was significantly different from the other four scenarios (Tukey's test, $p<0.05$; Figure 4).

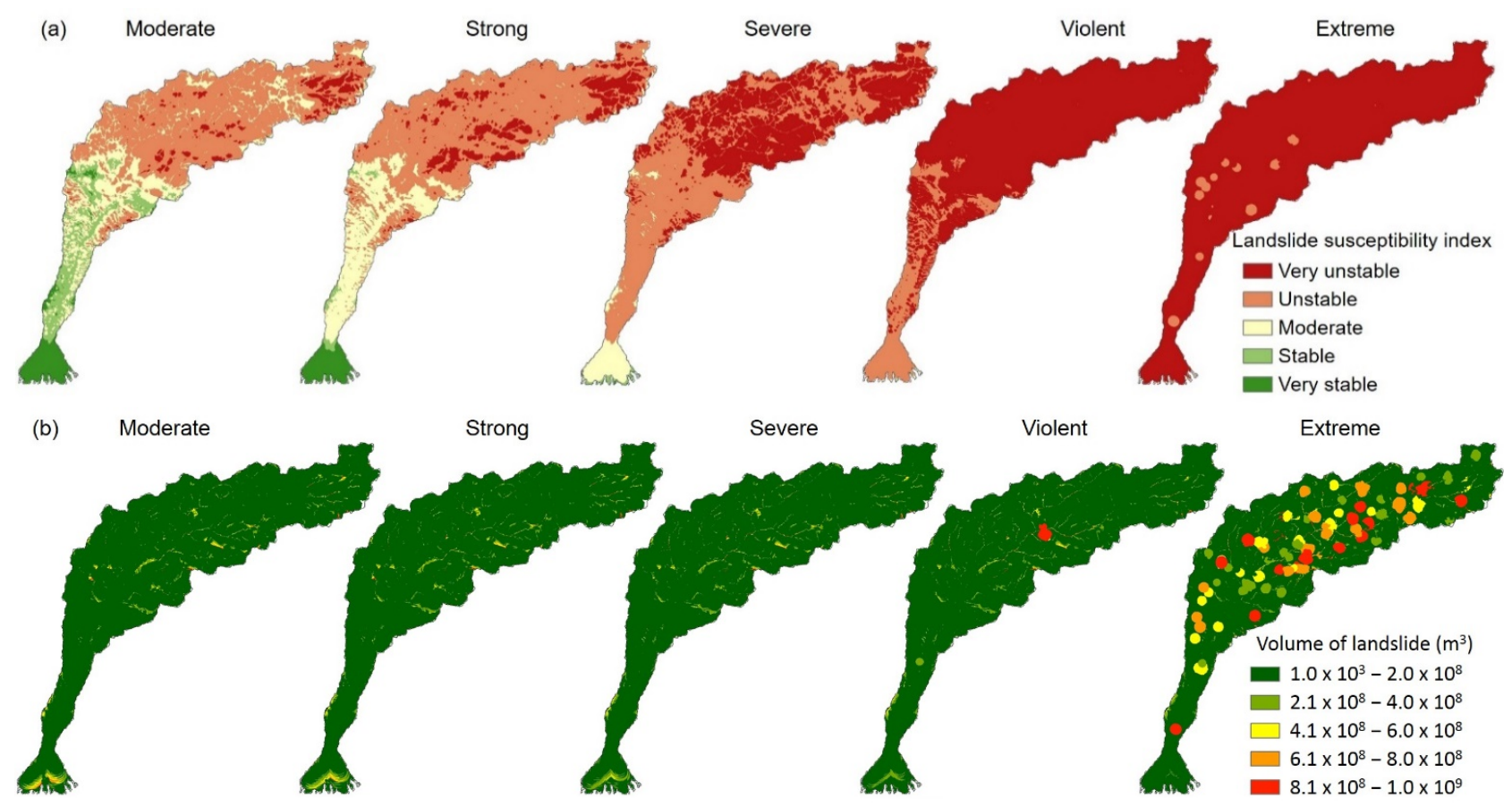

Figure 3. Maps of (a) landslide susceptibility index and (b) volume of landslide under five earthquake scenarios in the Mailuu-Suu catchment. 


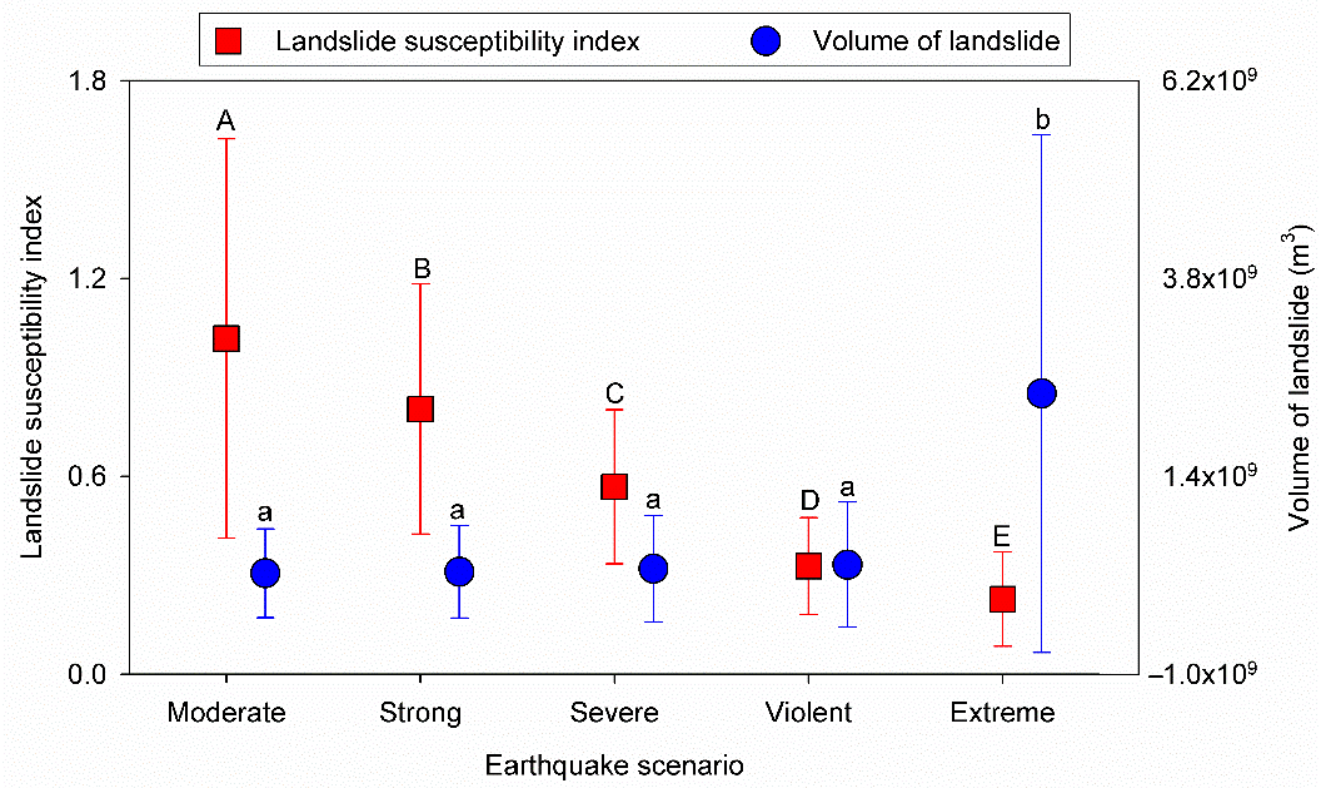

Figure 4. Comparisons of landslide susceptibility index and volume of landslide among five earthquake scenarios in the Mailuu-Suu catchment. The circle and square are mean values and the whisker is standard deviation. Different letters indicate significant differences between the earthquake scenarios (Tukey's multiple comparison test, $p<0.05$ ).

However, a significant difference in the average values of VOL was only observed between the extreme earthquake scenario $\left(2.4 \times 10^{8} \pm 3.1 \times 10^{8} \mathrm{~m}^{3}\right)$ and the other four scenarios (ranged between $2.2 \times 10^{7}$ and $3.3 \times 10^{7} \mathrm{~m}^{3}$ ) (Tukey's test, $p<0.05$; Figure 4 ). In other words, although the VOL rose with the increase in earthquake strength (Figure 3b), the average values of VOL were not significant different among the first four earthquake scenarios (Tukey's test, $p>0.05$; Figure 4). Interestingly, the areas with large VOL (colours of yellow, orange, and red in Figure $3 b$ ) were identified as mosaic clusters under the extreme earthquake scenario. Such mosaic clusters indicate the most susceptible areas to potential heavy earthquakes.

The selected nine environmental variables were classified into four to eight classes (Figure 5), and the variations of LSI and VOL were then estimated among the classes for each environmental variable. In details, the average values of LSI reduced with the increase in elevation, slope, annual precipitation, distances to faults, roads, and streams (Table 3). Concerning the land cover, the areas with cropland and sparse vegetation (dominated in the downstream areas; ranged between 0.26 and 1.52) were stable, whereas water/snow and bare areas (dominated in the upstream areas; ranged between 0.10 and 0.56 ) were identified as unstable areas (Table 3). Concerning the soil type, it changed along the longitudinal stream networks, and therefore the average value of LSI increased along the soil type (i.e., along the longitudinal stream networks) (Table 3). However, there were no clear patterns among classes for aspect (Table 3). 
(a)

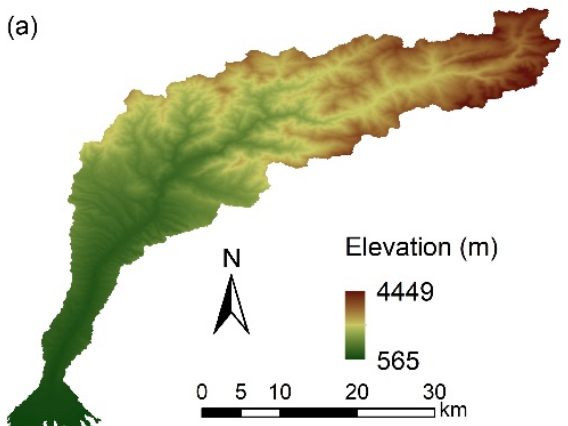

(d)

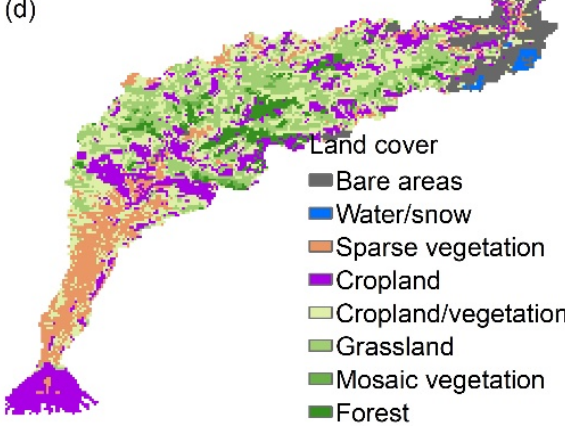

(g)

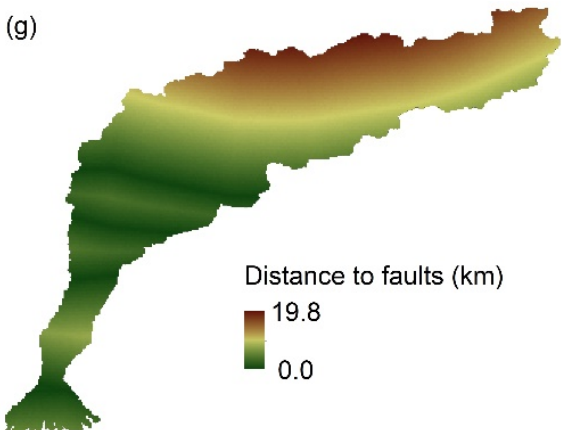

(b)

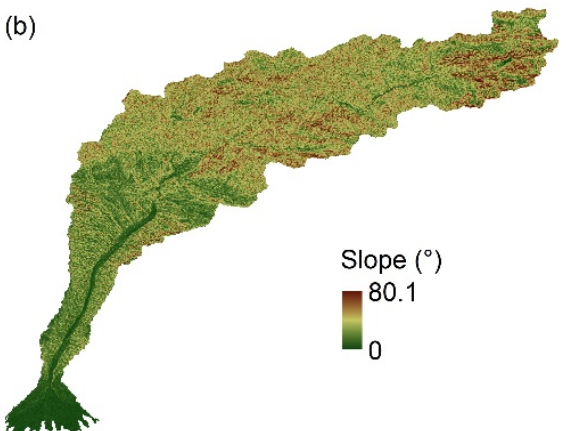

(e)
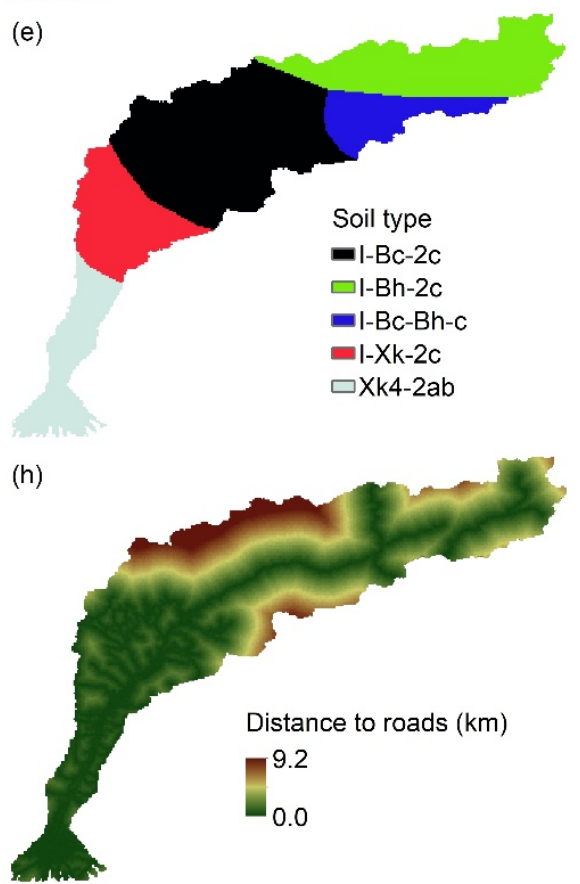

(c)

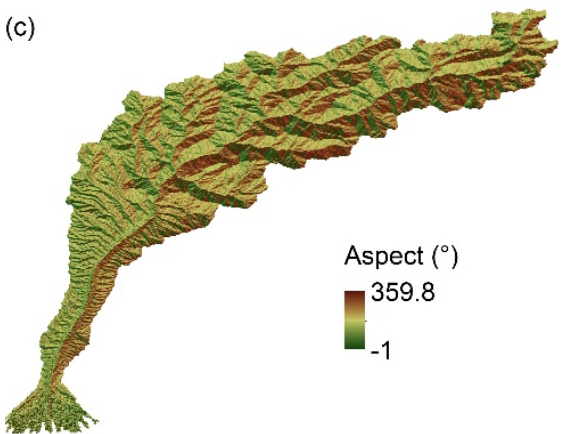

(f)

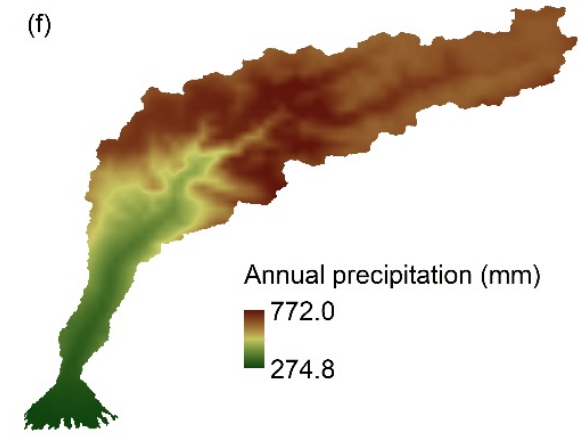

(i)

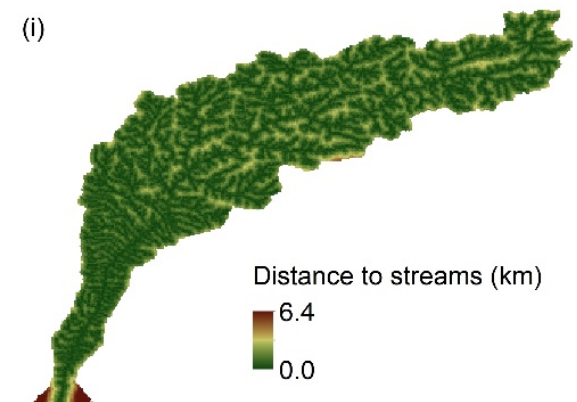

Figure 5. Distributions of variables selected for the correlation analysis in the Mailuu-Suu catchment: (a) elevation, (b) slope, (c) aspect, (d) land cover, (e) soil type, (f) annual precipitation between 1970 and 2000, distance to (g) faults, (h) roads, and (i) streams.

The general patterns of VOL were slightly different from the patterns of LSI. In detail, the highest VOL was observed in moderate elevation areas (i.e., 1000-2000 m; ranged between $2.5 \times 10^{7}$ and $2.6 \times 10^{8} \mathrm{~m}^{3}$ ) and the lowest value was in the high elevation areas (i.e., >3000 m; ranged between $1.4 \times 10^{7}$ and $1.0 \times 10^{8} \mathrm{~m}^{3}$ ) (Table 3). The VOL reduced with the increase in slope, whereas an opposite pattern was observed for the annual precipitation (Table 3). Concerning the land cover, a low VOL was observed in the water/snow and bare areas (ranged between $6.6 \times 10^{6}$ and $8.7 \times 10^{7} \mathrm{~m}^{3}$ ), whereas the high values were in the grassland and mosaic vegetation areas (ranged between $3.0 \times 10^{7}$ and $4.2 \times 10^{8} \mathrm{~m}^{3}$ ) (Table 3). Concerning the soil type, a high VOL was observed in the areas with soil type I-Bc-2c (Lithosols Chromic Cambisols; ranged between $3.0 \times 10^{7}$ and $2.6 \times 10^{8} \mathrm{~m}^{3}$ ) which distributed in the middle section of the Mailuu-Suu catchment (Table 3). However, there were no clear patterns among classes for the aspect and three proximity variables (Table 3). 
Table 3. Averages of landslide susceptibility index and volume of landslide across the classes of environmental variables under five earthquake scenarios.

\begin{tabular}{|c|c|c|c|c|c|c|c|c|c|c|}
\hline \multirow{2}{*}{ Variable/Class } & \multicolumn{5}{|c|}{ Landslide Susceptibility Index } & \multicolumn{5}{|c|}{ Volume of Landslide $\left(\mathrm{m}^{3}\right)$} \\
\hline & Moderate & Strong & Severe & Violent & Extreme & Moderate & Strong & Severe & Violent & Extreme \\
\hline \multicolumn{11}{|l|}{ Elevation (m) } \\
\hline 576-1000 & 2.03 & 1.45 & 0.96 & 0.56 & 0.32 & $2.0 \times 10^{7}$ & $2.3 \times 10^{7}$ & $3.1 \times 10^{7}$ & $4.5 \times 10^{7}$ & $1.3 \times 10^{8}$ \\
\hline $1000-2000$ & 1.06 & 0.85 & 0.61 & 0.36 & 0.25 & $2.5 \times 10^{7}$ & $2.8 \times 10^{7}$ & $3.3 \times 10^{7}$ & $3.9 \times 10^{7}$ & $2.6 \times 10^{8}$ \\
\hline 2000-3000 & 0.74 & 0.62 & 0.45 & 0.25 & 0.20 & $2.4 \times 10^{7}$ & $2.4 \times 10^{7}$ & $2.6 \times 10^{7}$ & $2.8 \times 10^{7}$ & $3.1 \times 10^{8}$ \\
\hline$>3000$ & 0.64 & 0.53 & 0.38 & 0.21 & 0.13 & $1.4 \times 10^{7}$ & $1.4 \times 10^{7}$ & $1.5 \times 10^{7}$ & $1.5 \times 10^{7}$ & $1.0 \times 10^{8}$ \\
\hline \multicolumn{11}{|l|}{ Slope $\left({ }^{\circ}\right)$} \\
\hline $0-10$ & 1.58 & 1.17 & 0.79 & 0.46 & 0.29 & $3.6 \times 10^{7}$ & $3.8 \times 10^{7}$ & $4.2 \times 10^{7}$ & $5.4 \times 10^{7}$ & $2.0 \times 10^{8}$ \\
\hline $10-25$ & 1.01 & 0.81 & 0.58 & 0.34 & 0.24 & $2.5 \times 10^{7}$ & $2.8 \times 10^{7}$ & $3.4 \times 10^{7}$ & $3.9 \times 10^{7}$ & $2.7 \times 10^{8}$ \\
\hline $25-40$ & 0.74 & 0.61 & 0.45 & 0.25 & 0.19 & $1.2 \times 10^{7}$ & $1.3 \times 10^{7}$ & $1.4 \times 10^{7}$ & $1.5 \times 10^{7}$ & $2.3 \times 10^{8}$ \\
\hline$>40$ & 0.60 & 0.50 & 0.36 & 0.19 & 0.17 & $9.4 \times 10^{6}$ & $1.1 \times 10^{7}$ & $1.1 \times 10^{7}$ & $1.1 \times 10^{7}$ & $2.4 \times 10^{8}$ \\
\hline \multicolumn{11}{|l|}{ Aspect $\left(^{\circ}\right)$} \\
\hline $\mathrm{N}(0-22.5,337.5-360)$ & 0.86 & 0.70 & 0.50 & 0.28 & 0.20 & $2.4 \times 10^{7}$ & $2.6 \times 10^{7}$ & $2.8 \times 10^{7}$ & $3.0 \times 10^{7}$ & $2.3 \times 10^{8}$ \\
\hline NE (22.5-67.5) & 1.04 & 0.83 & 0.59 & 0.34 & 0.25 & $1.4 \times 10^{7}$ & $1.4 \times 10^{7}$ & $1.7 \times 10^{7}$ & $1.9 \times 10^{7}$ & $2.6 \times 10^{8}$ \\
\hline E (67.5-112.5) & 1.18 & 0.92 & 0.65 & 0.38 & 0.25 & $1.8 \times 10^{7}$ & $2.4 \times 10^{7}$ & $2.4 \times 10^{7}$ & $3.2 \times 10^{7}$ & $2.2 \times 10^{8}$ \\
\hline SE (112.5-157.5) & 1.14 & 0.88 & 0.62 & 0.35 & 0.24 & $2.0 \times 10^{7}$ & $2.2 \times 10^{7}$ & $3.2 \times 10^{7}$ & $3.8 \times 10^{7}$ & $2.0 \times 10^{8}$ \\
\hline$S(157.5-202.5)$ & 1.00 & 0.79 & 0.55 & 0.32 & 0.23 & $2.2 \times 10^{7}$ & $2.4 \times 10^{7}$ & $2.5 \times 10^{7}$ & $3.5 \times 10^{7}$ & $2.7 \times 10^{8}$ \\
\hline SW (202.5-247.5) & 1.09 & 0.86 & 0.61 & 0.35 & 0.25 & $2.6 \times 10^{7}$ & $2.8 \times 10^{7}$ & $3.7 \times 10^{7}$ & $3.8 \times 10^{7}$ & $2.9 \times 10^{8}$ \\
\hline W (247.5-292.5) & 1.03 & 0.81 & 0.57 & 0.34 & 0.23 & $2.1 \times 10^{7}$ & $2.3 \times 10^{7}$ & $2.5 \times 10^{7}$ & $3.1 \times 10^{7}$ & $2.3 \times 10^{8}$ \\
\hline NW (292.5-337.5) & 0.87 & 0.70 & 0.50 & 0.29 & 0.20 & $3.0 \times 10^{7}$ & $3.1 \times 10^{7}$ & $3.2 \times 10^{7}$ & $3.4 \times 10^{7}$ & $2.1 \times 10^{8}$ \\
\hline \multicolumn{11}{|l|}{ Land cover } \\
\hline Forest & 0.75 & 0.62 & 0.45 & 0.25 & 0.21 & $2.1 \times 10^{7}$ & $2.4 \times 10^{7}$ & $2.5 \times 10^{7}$ & $2.5 \times 10^{7}$ & $3.2 \times 10^{8}$ \\
\hline Mosaic vegetation & 0.85 & 0.71 & 0.51 & 0.30 & 0.25 & $3.0 \times 10^{7}$ & $3.0 \times 10^{7}$ & $3.3 \times 10^{7}$ & $3.5 \times 10^{7}$ & $4.2 \times 10^{8}$ \\
\hline Grassland & 0.87 & 0.71 & 0.52 & 0.30 & 0.21 & $3.3 \times 10^{7}$ & $3.4 \times 10^{7}$ & $3.9 \times 10^{7}$ & $4.2 \times 10^{7}$ & $3.0 \times 10^{8}$ \\
\hline Cropland/vegetation & 0.96 & 0.78 & 0.56 & 0.33 & 0.24 & $2.3 \times 10^{7}$ & $2.5 \times 10^{7}$ & $2.9 \times 10^{7}$ & $3.6 \times 10^{7}$ & $2.6 \times 10^{8}$ \\
\hline Cropland & 1.52 & 1.07 & 0.70 & 0.39 & 0.28 & $2.0 \times 10^{7}$ & $2.2 \times 10^{7}$ & $2.6 \times 10^{7}$ & $3.0 \times 10^{7}$ & $2.3 \times 10^{8}$ \\
\hline Sparse vegetation & 1.40 & 1.09 & 0.76 & 0.45 & 0.26 & $1.1 \times 10^{7}$ & $1.6 \times 10^{7}$ & $2.1 \times 10^{7}$ & $2.6 \times 10^{7}$ & $1.4 \times 10^{8}$ \\
\hline Water/Snow & 0.51 & 0.43 & 0.30 & 0.15 & 0.15 & $6.6 \times 10^{6}$ & $6.6 \times 10^{6}$ & $6.6 \times 10^{6}$ & $6.6 \times 10^{6}$ & $7.7 \times 10^{7}$ \\
\hline Bare areas & 0.56 & 0.46 & 0.33 & 0.17 & 0.10 & $1.1 \times 10^{7}$ & $1.2 \times 10^{7}$ & $1.2 \times 10^{7}$ & $1.3 \times 10^{7}$ & $8.7 \times 10^{7}$ \\
\hline \multicolumn{11}{|l|}{ Soil type } \\
\hline I-Bh-2c & 0.73 & 0.61 & 0.44 & 0.25 & 0.19 & $1.5 \times 10^{7}$ & $1.6 \times 10^{7}$ & $1.7 \times 10^{7}$ & $1.8 \times 10^{7}$ & $2.4 \times 10^{8}$ \\
\hline $\mathrm{I}-\mathrm{Bc}-\mathrm{Bh}-\mathrm{c}$ & 0.71 & 0.59 & 0.43 & 0.24 & 0.19 & $2.7 \times 10^{7}$ & $2.7 \times 10^{7}$ & $2.8 \times 10^{7}$ & $2.9 \times 10^{7}$ & $3.2 \times 10^{8}$ \\
\hline $\mathrm{I}-\mathrm{Bc}-2 \mathrm{c}$ & 0.83 & 0.68 & 0.50 & 0.28 & 0.21 & $3.0 \times 10^{7}$ & $3.2 \times 10^{7}$ & $3.7 \times 10^{7}$ & $4.1 \times 10^{7}$ & $2.6 \times 10^{8}$ \\
\hline $\mathrm{I}-\mathrm{Xk}-2 \mathrm{c}$ & 1.30 & 1.03 & 0.73 & 0.44 & 0.29 & $1.7 \times 10^{7}$ & $1.9 \times 10^{7}$ & $1.9 \times 10^{7}$ & $2.7 \times 10^{7}$ & $2.0 \times 10^{8}$ \\
\hline $\mathrm{Xk} 4-2 \mathrm{ab}$ & 2.17 & 1.53 & 0.99 & 0.58 & 0.33 & $1.4 \times 10^{7}$ & $2.2 \times 10^{7}$ & $3.1 \times 10^{7}$ & $4.6 \times 10^{7}$ & $1.4 \times 10^{8}$ \\
\hline \multicolumn{11}{|l|}{ Precipitation $(\mathrm{mm})$} \\
\hline $278-400$ & 1.91 & 1.38 & 0.92 & 0.54 & 0.31 & $1.6 \times 10^{7}$ & $2.2 \times 10^{7}$ & $2.8 \times 10^{7}$ & $3.9 \times 10^{7}$ & $1.3 \times 10^{8}$ \\
\hline $400-550$ & 1.21 & 0.96 & 0.69 & 0.41 & 0.29 & $1.6 \times 10^{7}$ & $1.8 \times 10^{7}$ & $2.1 \times 10^{7}$ & $3.3 \times 10^{7}$ & $2.2 \times 10^{8}$ \\
\hline $550-700$ & 0.76 & 0.63 & 0.46 & 0.26 & 0.20 & $2.1 \times 10^{7}$ & $2.2 \times 10^{7}$ & $2.3 \times 10^{7}$ & $2.4 \times 10^{7}$ & $2.6 \times 10^{8}$ \\
\hline$>700$ & 0.76 & 0.63 & 0.46 & 0.26 & 0.19 & $3.3 \times 10^{7}$ & $3.5 \times 10^{7}$ & $4.3 \times 10^{7}$ & $4.5 \times 10^{7}$ & $2.9 \times 10^{8}$ \\
\hline \multicolumn{11}{|l|}{ Distance to faults $(\mathrm{km})$} \\
\hline $0-5$ & 1.38 & 1.06 & 0.73 & 0.43 & 0.28 & $2.0 \times 10^{7}$ & $2.3 \times 10^{7}$ & $2.6 \times 10^{7}$ & $3.5 \times 10^{7}$ & $2.1 \times 10^{8}$ \\
\hline $5-10$ & 0.80 & 0.65 & 0.46 & 0.26 & 0.17 & $2.7 \times 10^{7}$ & $2.8 \times 10^{7}$ & $3.3 \times 10^{7}$ & $3.7 \times 10^{7}$ & $2.3 \times 10^{8}$ \\
\hline $10-15$ & 0.74 & 0.61 & 0.45 & 0.25 & 0.19 & $2.6 \times 10^{7}$ & $2.7 \times 10^{7}$ & $3.1 \times 10^{7}$ & $3.2 \times 10^{7}$ & $2.9 \times 10^{8}$ \\
\hline$>15$ & 0.81 & 0.67 & 0.49 & 0.28 & 0.23 & $1.4 \times 10^{7}$ & $1.5 \times 10^{7}$ & $1.6 \times 10^{7}$ & $1.7 \times 10^{7}$ & $2.6 \times 10^{8}$ \\
\hline \multicolumn{11}{|l|}{ Distance to roads $(\mathrm{km})$} \\
\hline $0-1$ & 1.28 & 0.98 & 0.68 & 0.40 & 0.26 & $2.2 \times 10^{7}$ & $2.4 \times 10^{7}$ & $2.9 \times 10^{7}$ & $3.5 \times 10^{7}$ & $2.1 \times 10^{8}$ \\
\hline $1-2$ & 0.80 & 0.66 & 0.47 & 0.27 & 0.18 & $2.3 \times 10^{7}$ & $2.5 \times 10^{7}$ & $2.6 \times 10^{7}$ & $3.4 \times 10^{7}$ & $2.6 \times 10^{8}$ \\
\hline $2-3$ & 0.77 & 0.63 & 0.46 & 0.26 & 0.22 & $2.2 \times 10^{7}$ & $2.2 \times 10^{7}$ & $2.8 \times 10^{7}$ & $3.0 \times 10^{7}$ & $3.8 \times 10^{8}$ \\
\hline$>3$ & 0.76 & 0.63 & 0.46 & 0.26 & 0.19 & $2.4 \times 10^{7}$ & $2.5 \times 10^{7}$ & $2.8 \times 10^{7}$ & $2.9 \times 10^{7}$ & $2.1 \times 10^{8}$ \\
\hline \multicolumn{11}{|l|}{ Distance to streams $(\mathrm{km})$} \\
\hline $0-0.1$ & 1.10 & 0.88 & 0.63 & 0.37 & 0.24 & $4.0 \times 10^{7}$ & $4.3 \times 10^{7}$ & $5.3 \times 10^{7}$ & $6.5 \times 10^{7}$ & $2.5 \times 10^{8}$ \\
\hline $0.1-0.2$ & 1.07 & 0.85 & 0.60 & 0.35 & 0.24 & $1.5 \times 10^{7}$ & $1.6 \times 10^{7}$ & $1.7 \times 10^{7}$ & $1.9 \times 10^{7}$ & $2.1 \times 10^{8}$ \\
\hline $0.2-0.3$ & 0.97 & 0.78 & 0.55 & 0.32 & 0.24 & $1.6 \times 10^{7}$ & $1.7 \times 10^{7}$ & $1.8 \times 10^{7}$ & $2.1 \times 10^{7}$ & $2.5 \times 10^{8}$ \\
\hline$>0.3$ & 0.94 & 0.73 & 0.51 & 0.28 & 0.20 & $1.6 \times 10^{7}$ & $1.7 \times 10^{7}$ & $1.9 \times 10^{7}$ & $2.1 \times 10^{7}$ & $2.5 \times 10^{8}$ \\
\hline
\end{tabular}

\subsection{Relationship between Landslide Metrics and Environmental Variables}

The relative importance of each environmental variable for the explanation of landslide metrics was performed using the machine-learning-based random forest analysis. The results indicated that the explanatory powers of LSI (ranged between $28.47 \%$ and $87.85 \%$ ) were significantly higher than that of VOL (ranged between $11.07 \%$ and $19.22 \%$ ) (Figure 6). The explanatory power reduced with the increase in the earthquake level, except in the extreme scenario of VOL (Figure 6). Overall, the most important environmental variable was distance to faults (ranged between $30.28 \%$ and $46.05 \%$ ) for the explanation 
of LSI, followed by slope, annual precipitation, and elevation (Figure 6a), whereas annual precipitation (ranged between $10.91 \%$ and $37.14 \%$ ) was identified as the most important environmental variable for the explanation of VOL, followed by elevation, slope, and distance to faults (Figure 6b). The explanatory powers of all the other five environmental variables were relatively low, and the variable with the lowest explanatory power was aspect (LSI: 5.59-16.16\%; VOL: 1.04-4.86\%; Figure 6).
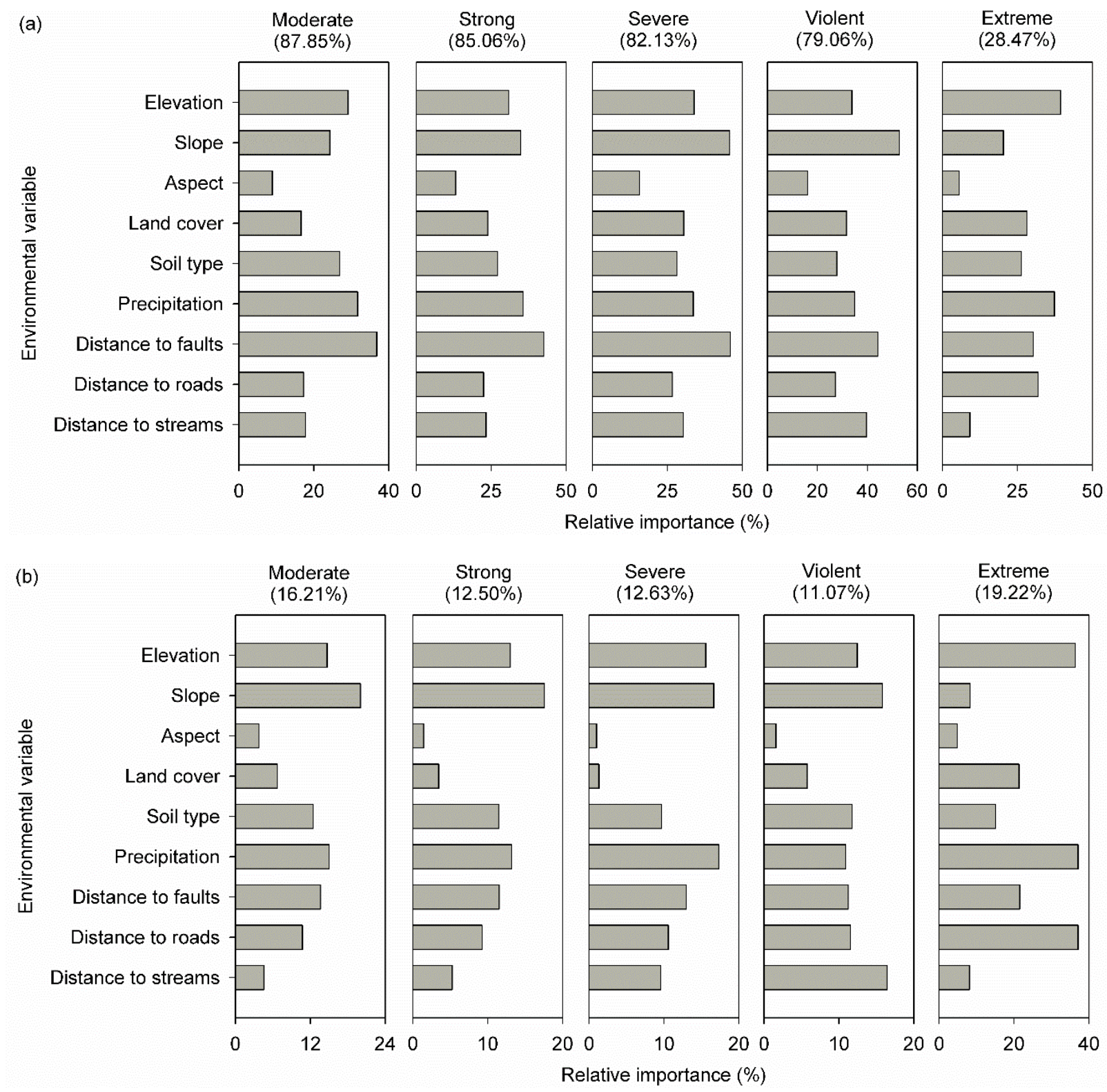

Figure 6. Relative importance of environmental variables for landslide metrics: (a) landslide susceptibility index and (b) volume of landslide under five earthquake scenarios. The value in bracket refers to the explanatory power of the random forest analysis.

\section{Discussion}

The generation of landslide susceptibility maps at an early stage of landslide risk assessment has a crucial importance for safe and economic planning. By simultaneous assessment of both LSI and VOL, this study developed landslide susceptibility maps for the seismic prone Mailuu-Suu catchment under five earthquake scenarios. The simulations made in this study can undoubtedly improve the understanding of the seismically vulner- 
able areas and the important triggering variables at this radioactive polluted catchment. Nevertheless, we are aware of the shortcomings of the present simulations, and suggestions for the follow-up studies are discussed in this section.

\subsection{Landslide Susceptibility Index and Volume of Landslide}

Referring to the specificity of geologic and natural conditions, the Mailuu-Suu catchment is a region with frequent high-seismic and geodynamic activities [13,48,52]. The landslide susceptibility assessment by means of LSI and VOL indicates the probability of landslides in this catchment. The floodplain at the mouth of the Mailuu-Suu catchment was identified as the most stable zone. This area is mainly flatland near the Ferghana Valley. The identification of floodplain as the stable zone was also reported in the Chittagong Hilly Areas of Bangladesh by Rabby and Li [42]. The vulnerable areas to landslide were found to be dominated in the upstream areas (Figure 3). This is slightly different from the findings of Torgoev et al. who reported that landslides frequently occurred in the mid-stream of the Mailuu-Suu [50]. A possible reason for the different findings lies in the definition of the upstream and mid-stream areas. In the present study, the defined upstream areas included both high and moderate mountain (i.e., mid-stream) areas. In addition, the Scoops3D model considers the influence of groundwater on local landslides as well. This makes the simulation more precise than the method of geological survey [33]. As an advantage of Scoops3D, a series of earthquake scenarios, ranging between moderate (M 5.0) and extreme (M 9.0), can be incorporated into the scenario analysis. It is reasonable that the values of LSI reduced with the increase in earthquake level, and a similar finding was reported by $\mathrm{Li}$ et al. [56]. Under the most frequently occurred earthquake level in the Mailuu-Suu catchment (i.e., the moderate earthquake scenario), the downstream areas were stable or very stable, where most residents and a large number of radioactive tailing ponds exist, indicating the relatively low influence of landslides on society and radioactive problems in this catchment. Nevertheless, this general spatial pattern would be quite different once the hazard level rises; for example, under the extreme earthquake scenario, the entire Mailuu-Suu catchment was classified as unstable area in the aspect of LSI.

Similar patterns of LSI were not observed for the VOL in this catchment. The VOL did not rise substantially with the increase in the earthquake level under M 8.0 (i.e., from moderate to violent). The VOL was, however, significantly higher under the extreme scenario than under the other four scenarios. By means of differential synthetic aperture radar interferometry analysis, Piroton et al. [52] found slow displacements of soil columns and concluded the existence of long-term slow sliding activities in the Mailuu-Suu catchment. Under the effect of low earthquake strength (e.g., moderate to severe), the VOL maintained a low level with a low number of mosaic clusters. With the triggering of violent or extreme earthquakes, these long-term slow displacements of soil columns could change into a catastrophic release of volume with a large number of mosaic clusters, as indicated in this case study. Besides the effect of earthquakes, a large number of landslides were caused by other types of hazards in this catchment. For example, in April 1958, about 50\% of tailing materials were released from the radioactive tailing pond 7 into the nearby river network. The cause of this accident were the combined effects of heavy rainfall and a poor design of the tailing dam in the Mailuu-Suu catchment [46,51].

\subsection{Relationship between Landslide Metrics and Environmental Variables}

As one of the most disastrous natural hazards, land sliding is one of the complex geomorphic processes that is affected by several triggering factors, which differ greatly from region to region $[9,36,37]$. The relative importance analysis indicated that distance to faults, precipitation, slope, and elevation were more relevant to the structure of the spatial patterns of LSI and VOL than other environmental variables. The influence of fault lines on the landscape vulnerability has been long recognised [13,50], i.e., the closer to the fault lines, the more dangerous the landscape. The importance of precipitation was supported by the finding of Dai and Lee [75] who investigated the relationship between the 
occurrence of landslides and precipitation in Hong Kong, and concluded that a $12 \mathrm{~h}$ rolling precipitation is most important factor in predicting the number of landslides. Similarly, Piroton et al. [52] reported that intensive precipitations and rapid melting contributed to the activation of some landslides in 2017 in the Mailuu-Suu catchment. The importance of slope has been mentioned in many previous studies [8,13,42]. Generally, landslides do not occur on a gentle slope, as the shear stress is too low, and an increase in slope gradient can potentially raise the likelihood of land sliding [15]. A colluvial landslide event mainly occurs in the moderate slope zone, as shown in Ma [15] and Zhou [65]. However, LSI and VOL showed linear correlations with the slope in our case. The importance of elevation lies in the fact that it controls temperature and vegetation. The occurrences of landslides rose with the increase in elevation before reaching a threshold elevation, where the landslide probability decreases as a result of soil characteristics or other geotechnical parameters $[13,61]$. This is in line with our findings in which the highest VOL was observed in the moderate elevation zones. As the third topographic variable used in this study, the aspect was relatively unimportant, but it was found to be important in the study of Three Gorges Reservoir in China, where the southeast aspect represented the highest occurrence probability of colluvial landslides [65]. The other two proximity variables (i.e., distance to roads and streams) were also identified as unimportant triggers in structuring the spatial patterns of LSI and VOL. Similar findings were reported by Polykretis et al. [13] in the Krios and Krathis catchments in Greece. However, the importance of proximity variables has been found in few studies; for example, $43 \%$ of the colluvial landslides occurred within the range of $50 \mathrm{~m}$ from roads and $38 \%$ within the range of $200 \mathrm{~m}$ from streams in the Three Gorges Reservoir in China [65].

By comparing the spatial distribution of LSI along the gradients of environmental variables, LSI was found to be negatively correlated to elevation, slope, precipitation, distances to faults, roads, and streams. Such relationships reflect the importance of these environmental variables. However, the patterns of land cover can also reflect the spatial distribution of LSI. Due to the effect of vegetation, Chalkias et al. [76] found that most cropland areas were vulnerable to landslides on the Peloponnese Peninsula in Greece. This is in contrast with our results, where the most stable zones were dominated by cropland and sparse vegetation in the downstream areas, and the unstable zones were located in the high mountain with water/snow and bare areas. The high susceptibility level in the snow and bare areas was also proven by the studies of Rahman et al. [37] and Chalkias et al. [76], where the presence of rock masses does not support any vegetation in the higher slopes. Based on the same effect of vegetation, the forest cover can protect the mountainous slopes from climatic effects and mass movements as the roots hold the underneath soil and keep the slopes stable [37]. However, most forest areas cover the high- to mid-streams in the Mailuu-Suu catchment, where a high susceptibility level was identified. The spatial distribution of soil types was also in accordance with LSI; therefore, a clear correlation between LSI and soil type was indicated in this study.

Slight differences in such correlations were observed between VOL and LSI. However, it is necessary to note that the explanatory power of LSI $(79.06-87.85 \%$ under the first four earthquake scenarios) was significantly higher than that of VOL (only 11.07-16.21\% under the first four earthquake scenarios). Therefore, the relationship analysis between LSI and the environmental variables is more meaningful than that between VOL and the environmental variables from a statistical point of view.

\subsection{Shortcomings of the Modelling Approach}

This section discusses the main limitations of this study.

First, this study faced challenges by the lack of adequate input data: (a) the input soil data were calculated based on six representative samples instead of a large number of soil samples; (b) as the grid layer of underground water was not available in this catchment, one averaged pore water pressure value was used for the entire catchment; and (c) the DEM with a resolution of $10 \mathrm{~m}$ was used in this simulation, and the generated simulations 
with low resolution data may lead to potential inaccuracies (e.g., a lack of representation of the actual on-ground topographic features and an increased loss of detailed properties of LSI and VOL). In this sense, a high resolution of DEM, for instance, the airborne LIDAR (the light detection and ranging, at a resolution of $30 \mathrm{~cm}$ or better) data, may support increasing the precision of the simulations, but it will increase the computation time and produce a large size of output files, and this will cause further problems (e.g., longer computation time for further analyses, beyond the limits of the programs, and requirements of advancement in computing facilities which can handle extremely large datasets) for the following statistical analyses.

Second, the limitations of Scoops3D itself can also affect the simulated results: (a) the limit equilibrium method does not allow progressive failure, and failures can only occur simultaneously along one single failure surface; (b) Scoops3D does not take the sitespecific features (e.g., discontinuity of local soil layer, external loads, non-linear strengths, partially submerged slopes, tension cracks, and complex failure-surface geometry) into consideration; and (c) the volume of failure is predefined with the potential slip surfaces. This predefined value can lead to changes in the simulated results and strongly depends on the experiences of the modellers [15].

Third, from the data preparation to the result generation, uncertainties may be introduced at each stage for the physically-based models. The input variables (i.e., soil parameters and pore pressure) were determined in the laboratory or from scientific experiences. The actual situation of soil and groundwater might be represented with limited accuracy due to a limited number of samples. In addition, the temporal variability of soil materials and pore water pressure caused by long-term erosion, land cover change and climate change (e.g., temperature and precipitation) cannot be considered in the simulations of Scoops3D. Uncertainties regarding the geometric parameters can be introduced by the predefined slip surface. Some simulations assume a shallow-seated landslide, while others assume a deep-seated landslide. Moreover, other site-specific features, as mentioned above, can also contribute to geometric uncertainties [33]. Concerning the earthquake loading, the proposed correlation between the horizontal pseudo-acceleration coefficient and the earthquake magnitude was obtained based on scientific experiences, but was not always in absolute agreement, since the damage of an earthquake can be also affected by many other factors, including the earthquake's depth, its geographical features, and so on. In this sense, follow-up studies should be carried out, particularly when sufficient in situ measurements of the geographical parameters, soil properties, and underground pore water pressure in the Mailuu-Suu catchment have been obtained.

Last but not least, a calibration between the simulated and measured landslide metrics could not be performed due to the lack of historical earthquake-induced landslide distributions and VOL in this remote area. However, the installation of a turbidity monitoring system is currently being investigated [77], which would allow calibration in the follow-up studies.

\section{Conclusions}

To date, the risk monitoring program plays an increasingly important role in emergency management because it can strengthen the sustainable development of society, the economy, and the environment [78]. As the first step of the risk monitoring program, an understanding of earthquake-induced landslides by means of the modelling approaches is essential in the landslide risk management process. This is especially important in Central Asia, where a large number of radioactive legacy sites are likely to be destroyed under the effect of landslides, leading to immeasurable environmental and political problems. A combined assessment of both LSI and VOL under a series of earthquake scenarios can undoubtedly (1) deepen the understanding of the formation mechanism and the process of landslides in the seismic prone areas and (2) assist the disaster management authorities to develop site-specific mitigation measures for landslide hazards, in order to avoid damages to the infrastructure and facilities, as well as loss of human lives in the future. 
This study concluded that the susceptibility level rose with the increase in earthquake strength, and the upstream areas were more seismically vulnerable than the downstream areas in the Mailuu-Suu catchment. The developed maps of LSI and VOL can serve as a guideline to trigger more detailed, site-specific investigations and analyses in this catchment. The identification of important triggers of landslides shall be considered by the local stakeholders and decision-makers in the landscape administration and land use design; in particular, localities of new infrastructures and facilities should be far from fault lines and areas with high precipitation, slope, and elevation in the Mailuu-Suu catchment. Although forests were not classified as stable areas in this study, proper land use planning and strict forest preservation measures are still highly recommended, as the bare areas were more vulnerable to landslides than forests within the same elevation zones. We are also aware that optimal input data and adequate calibration data from the historical earthquake-induced landslide events are necessary to perform an ideal model. The follow-up calibration studies are, therefore, needed in order to increase the simulation precision of physically-based models. Last but not least, the proposed modelling approaches in this study can save human and financial resources for the intensive in situ measurements of geometric profiles over space and time, and shall be, therefore, recommended for other geological disaster-prone regions that are either not reachable due to the natural geographical barriers or poorly equipped in terms of earthquake and landslide measurement technology.

Author Contributions: Conceptualization, F.L., C.K. and P.S.; methodology, F.L.; software, F.L.; validation, F.L.; formal analysis, F.L.; investigation, F.L., C.K. and P.S.; resources, F.L., C.K. and P.S.; data curation, F.L., C.K. and P.S.; writing-original draft preparation, F.L.; writing-review and editing, I.T., D.Z., M.L., B.T., A.B., C.K. and P.S.; visualization, F.L.; supervision, C.K. and P.S.; project administration, C.K. and P.S.; funding acquisition, C.K. and P.S. All authors have read and agreed to the published version of the manuscript.

Funding: This research was funded by the Federal Ministry of Education and Research of Germany (BMBF), grant numbers 03G0879A and 03G0879C.

Acknowledgments: We sincerely thank all contributors for the data collection. We kindly recognize the valuable comments of the anonymous reviewers that have helped to improve the quality of this work.

Conflicts of Interest: The authors declare no conflict of interest.

\section{References}

1. Reichenbach, P.; Rossi, M.; Malamud, B.D.; Mihir, M.; Guzzetti, F. A review of statistically-based landslide susceptibility models. Earth Sci. Rev. 2018, 180, 60-91. [CrossRef]

2. Temme, A.; Guzzetti, F.; Samia, J.; Mirus, B.B. The future of landslides' past-A framework for assessing consecutive landsliding systems. Landslides 2020, 17, 1519-1528. [CrossRef]

3. Galli, M.; Ardizzone, F.; Cardinali, M.; Guzzetti, F.; Reichenbach, P. Comparing landslide inventory maps. Geomorphology 2008, 94, 268-289. [CrossRef]

4. Chen, Y.M.; Chen, C.W.; Chao, Y.C.; Tung, Y.S.; Liou, J.J.; Li, H.C.; Cheng, C.T. Future Landslide characteristic assessment using ensemble climate change scenarios: A case study in Taiwan. Water 2020, 12, 564. [CrossRef]

5. Gariano, S.L.; Guzzetti, F. Landslides in a changing climate. Earth Sci. Rev. 2016, 162, 227-252. [CrossRef]

6. Calista, M.; Miccadei, E.; Piacentini, T.; Sciarra, N. Morphostructural, meteorological and seismic factors controlling landslides in weak rocks: The case studies of Castelnuovo and Ponzano (North East Abruzzo, Central Italy). Geosciences 2019, 9, 122. [CrossRef]

7. Carabella, C.; Miccadei, E.; Paglia, G.; Sciarra, N. Post-wildfire landslide hazard assessment: The case of the 2017 Montagna Del Morrone Fire (Central Apennines, Italy). Geosciences 2019, 9, 175. [CrossRef]

8. Psomiadis, E.; Papazachariou, A.; Soulis, K.X.; Alexiou, D.S.; Charalampopoulos, I. Landslide mapping and susceptibility assessment using geospatial analysis and earth observation data. Land 2020, 9, 133. [CrossRef]

9. Silalahi, F.E.S.; Arifianti, P.Y.; Hidayat, F. Landslide susceptibility assessment using frequency ratio model in Bogor, West Java, Indonesia. Geosci. Lett. 2019, 6, 10. [CrossRef]

10. Wang, Z.; Wang, D.; Guo, Q.; Wang, D. Regional landslide hazard assessment through integrating susceptibility index and rainfall process. Nat. Hazards 2020, 104, 2153-2173. [CrossRef]

11. Ozturk, U.; Pittore, M.; Behling, R.; Roessner, S.; Andreani, L.; Korup, O. How robust are landslide susceptibility estimates? Landslides 2021, 18, 681-695. [CrossRef] 
12. Marc, O.; Hovius, N.; Meunier, P.; Uchida, T.; Hayashi, S. Transient changes of landslide rates after earthquakes. Geology 2015, 43, 883-886. [CrossRef]

13. Polykretis, C.; Ferentinou, M.; Chalkias, C. A comparative study of landslide susceptibility mapping using landslide susceptibility index and artificial neural networks in the Krios River and Krathis River catchments (northern Peloponnesus, Greece). Bull. Eng. Geol. Environ. 2015, 74, 27-45. [CrossRef]

14. Khan, H.; Shafique, M.; Khan, M.A.; Bacha, M.A.; Shah, S.U.; Calligaris, C. Landslide susceptibility assessment using frequency ratio, a case study of northern Pakistan. Egypt. J. Remote Sens. Space Sci. 2019, 22, 11-24. [CrossRef]

15. Ma, C. Comparing and Evaluating Two Physically-Based Models: Openlisem and Scoops3d, for Landslide Volume Prediction. Ph.D. Thesis, University of Twente, Enschede, The Netherlands, 2018.

16. Massey, C.I.; Townsend, D.; Jones, K.; Lukovic, B.; Rhoades, D.; Morgenstern, R.; Rosser, B.; Ries, W.; Howarth, J.; Hamling, I.; et al. Volume characteristics of landslides triggered by the mw 7.8 2016 Kaikoura earthquake, New Zealand, derived from digital surface difference modeling. J. Geophys. Res. Earth Surf. 2020, 125, e2019JF005163. [CrossRef]

17. Marc, O.; Hovius, N.; Meunier, P.; Gorum, T.; Uchida, T. A seismologically consistent expression for the total area and volume of earthquake-triggered landsliding. J. Geophys. Res. Earth Surf. 2016, 121, 640-663. [CrossRef]

18. Marchesini, I.; Cencetti, C.; De Rosa, P. A preliminary method for the evaluation of the landslides volume at a regional scale. Geoinformatica 2009, 13, 277-289. [CrossRef]

19. Loew, S.; Gschwind, S.; Gischig, V.; Keller-Signer, A.; Valenti, G. Monitoring and early warning of the 2012 Preonzo catastrophic rockslope failure. Landslides 2017, 14, 141-154. [CrossRef]

20. Tang, C.; Tanyas, H.; van Westen, C.J.; Tang, C.; Fan, X.; Jetten, V.G. Analysing post-earthquake mass movement volume dynamics with multi-source DEMs. Eng. Geol. 2019, 248, 89-101. [CrossRef]

21. Zhang, S.; Zhang, L.M. Impact of the 2008 Wenchuan earthquake in China on subsequent long-term debris flow activities in the epicentral area. Geomorphology 2017, 276, 86-103. [CrossRef]

22. Kalantar, B.; Ueda, N.; Al-Najjar, H.A.H.; Halin, A.A. Assessment of convolutional neural network architectures for earthquakeinduced building damage detection based on pre- and post-event orthophoto images. Remote Sens. 2020, 12, 3529. [CrossRef]

23. Bricker, J.D.; Schwanghart, W.; Adhikari, B.R.; Moriguchi, S.; Roeber, V.; Giri, S. Performance of models for flash flood warning and hazard assessment: The 2015 Kali Gandaki landslide dam breach in Nepal. Mt. Res. Dev. 2017, 37, 5-15. [CrossRef]

24. Jaboyedoff, M.; Carrea, D.; Derron, M.H.; Oppikofer, T.; Penna, I.M.; Rudaz, B. A review of methods used to estimate initial landslide failure surface depths and volumes. Eng. Geol. 2020, 267, 105478. [CrossRef]

25. Han, Z.; Su, B.; Li, Y.; Ma, Y.; Wang, W.; Chen, G. Comprehensive analysis of landslide stability and related countermeasures: A case study of the Lanmuxi landslide in China. Sci. Rep. 2019, 9, 12407. [CrossRef] [PubMed]

26. Mulligan, R.P.; Franci, A.; Celigueta, M.A.; Take, W.A. Simulations of landslide wave generation and propagation using the particle finite element method. J. Geophys. Res. Oceans 2020, 125, e2019JC015873. [CrossRef]

27. Wang, L.; Zhang, X.; Tinti, S. Shallow landslides modeling using a particle finite element model with emphasis on landslide evolution. Earth Surf. Dynam. Discuss. 2019, 2019, 1-19.

28. Thiebes, B.; Bell, R.; Glade, T.; Jäger, S.; Mayer, J.; Anderson, M.; Holcombe, L. Integration of a limit-equilibrium model into a landslide early warning system. Landslides 2014, 11, 859-875. [CrossRef]

29. Bagherzadeh Khalkhali, A.; Kabiri Koochaksaraei, M. Evaluation of limit equilibrium and finite element methods in slope stability analysis-Case study of Zaremroud landslide, Iran. Comp. Eng. Phys. Model. 2019, 2, 1-15.

30. Hungr, O.; Salgado, F.M.; Byrne, P.M. Evaluation of a three-dimensional method of slope stability analysis. Can. Geotech. J. 1989, 26, 679-686. [CrossRef]

31. Lam, L.; Fredlund, D.G. A general limit equilibrium model for three-dimensional slope stability analysis. Can. Geotech. J. 1993, 30, 905-919. [CrossRef]

32. Mergili, M.; Marchesini, I.; Rossi, M.; Guzzetti, F.; Fellin, W. Spatially distributed three-dimensional slope stability modelling in a raster GIS. Geomorphology 2014, 206, 178-195. [CrossRef]

33. Reid, M.E.; Christian, S.B.; Brien, D.L.; Henderson, S.T. Scoops3D—Software to Analyze 3D Slope Stability Throughout a Digital Landscape; U.S. Geological Survey Techniques and Methods: Reston, Virginia, 2015.

34. van den Bout, B.; van Asch, T.W.J.; Hu, W.; Tang, C.; Mavrouli, O.; Jetten, V.G.; van Westen, C.J. Towards a model for structured mass movements: The OpenLISEM Hazard model 2.0a. Geosci. Model. Dev. Discuss. 2020, 13, 1-31.

35. Lee, K.; Suk, J.; Kim, H.; Jeong, S. Modeling of rainfall-induced landslides using a full-scale flume test. Landslides 2021, 18, 1153-1162. [CrossRef]

36. Milevski, I.; Dragićević, S.; Zorn, M. Statistical and expert-based landslide susceptibility modeling on a national scale applied to North Macedonia. Open Geosci. 2019, 11, 750-764. [CrossRef]

37. Rahman, G.; Rahman, A.U.; Bacha, A.S.; Mahmood, S. Assessment of landslide susceptibility using weight of evidence and frequency ratio model in Shahpur Valley, Eastern Hindu Kush. Nat. Hazards Earth Syst. Sci. 2021, $21,167$.

38. Li, F.; Kwon, Y.S.; Bae, M.J.; Chung, N.; Kwon, T.S.; Park, Y.S. Potential impacts of global warming on the diversity and distribution of stream insects in South Korea. Conserv. Biol. 2014, 28, 498-508. [CrossRef] [PubMed]

39. Li, F.; Shah, D.N.; Pauls, S.U.; Qu, X.; Cai, Q.; Shah, R.D.T. Elevational shifts of freshwater communities cannot catch up climate warming in the Himalaya. Water 2016, 8, 327. [CrossRef] 
40. Meneses, B.M.; Pereira, S.; Reis, E. Effects of different land use and land cover data on the landslide susceptibility zonation of road networks. Nat. Hazards Earth Syst. Sci. 2019, 19, 471-487. [CrossRef]

41. Shu, H.; Hürlimann, M.; Molowny-Horas, R.; González, M.; Pinyol, J.; Abancó, C.; Ma, J. Relation between land cover and landslide susceptibility in Val d'Aran, Pyrenees (Spain): Historical aspects, present situation and forward prediction. Sci. Total Environ. 2019, 693, 133557. [CrossRef]

42. Rabby, Y.W.; Li, Y. Landslide susceptibility mapping using integrated methods: A case study in the Chittagong Hilly Areas, Bangladesh. Geosciences 2020, 10, 483. [CrossRef]

43. Bontemps, N.; Lacroix, P.; Larose, E.; Jara, J.; Taipe, E. Rain and small earthquakes maintain a slowmoving landslide in a persistent critical state. Nat. Commun. 2020, 11, 780. [CrossRef]

44. Kim, S.W.; Chun, K.W.; Kim, M.; Catani, F.; Choi, B.; Seo, J.I. Effect of antecedent rainfall conditions and their variations on shallow landslide-triggering rainfall thresholds in South Korea. Landslides 2021, 18, 569-582. [CrossRef]

45. Ferlisi, S.; Marchese, A.; Peduto, D. Quantitative analysis of the risk to road networks exposed to slow-moving landslides: A case study in the Campania region (southern Italy). Landslides 2021, 18, 303-319. [CrossRef]

46. Torgoev, I.A.; Aleshin, Y.G.; Meleshko, A.V.; Havenith, H.B. Hazard mitigation for landslide dams in Mailuu-Suu valley (Kyrgyzstan). Ital. J. Eng. Geol. Environ. 2006, 99-102. [CrossRef]

47. Havenith, H.B.; Umaraliev, R.; Schlögel, R.; Torgoev, I. Past and Potential Future Socioeconomic Impacts of Environmental Hazards in Kyrgyzstan. In Kyrgyzstan: Political, Economic and Social Issues Edition: Central Asia: Economic and Political Issues; Perry, O.A., Ed.; NOVA Science Publishers: Hauppauge, NY, USA, 2017; pp. 63-113.

48. Havenith, H.B.; Torgoev, I.; Meleshko, A.; Alioshin, Y.; Torgoev, A.; Danneels, G. Landslides in the Mailuu-Suu Valley, Kyrgyzstanhazards and impacts. Landslides 2006, 3, 137-147. [CrossRef]

49. Torgoev, A.; Havenith, H.B. 2D dynamic studies combined with the surface curvature analysis to predict Arias Intensity amplification. J. Seismol. 2016, 20, 711-731. [CrossRef]

50. Torgoev, I.A.; Aleshin, Y.G.; Ashirov, G.E. Environmental Effects of Possible Landslide Catastrophes in the Areas of Radioactive Waste Warehousing in Kyrgyzstan (Central Asia). Available online: http://www.un-spider.org/sites/default/files/2-Landslide_ Impacts_\%28Institute\%20of\%20Physics\%20of\%20Kyrgyzstan\%29.pdf (accessed on 24 November 2019).

51. Saponaro, A.; Pilz, M.; Wieland, M.; Bindi, D.; Moldobekov, B.; Parolai, S. Landslide susceptibility analysis in data-scarce regions: The case of Kyrgyzstan. Bull. Eng. Geol. Environ. 2014, 74, 1117-1136. [CrossRef]

52. Piroton, V.; Schlögel, R.; Barbier, C.; Havenith, H.B. Monitoring the recent activity of landslides in the Mailuu-Suu Valley (Kyrgyzstan) using radar and optical remote sensing techniques. Geosciences 2020, 10, 164. [CrossRef]

53. ISDR. In Depth Review of Disaster Risk Reduction in the Kyrgyz Republic; Secretariat of the United Nations, International Strategy for Disaster Reduction, Sub-Regional Office for Central Asia and Caucasus: Bishkek, Kyrgyzstan, 2010.

54. Kunze, C.; Walter, U.; Wagner, F.; Schmidt, P.; Barnekow, U.; Gruber, A. Environmental impact and remediation of uranium tailings and waste rock dumps at Mailuu Suu (Kyrgyzstan). In Proceedings of the International Conference on Mine Closure and Environmental Remediation, Gera, Germany, 10-12 September 2007; pp. 10-12.

55. Salbu, B. Assessment of the radiological impact of gamma and radon dose rates at former U mining sites in Central Asia. J. Environ. Radioact. 2013, 123, 3-13.

56. Li, F.; Torgoev, I.; Zaredinov, D.; Li, M.; Talipov, B.; Belousova, A.; Kunze, C.; Schneider, P. Landslide-induced mass transport of radionuclides along transboundary Mailuu-Suu river networks in Central Asia. Remote Sens. 2021, 13, 698. [CrossRef]

57. Vandenhove, H.; Sweeck, L.; Mallants, D.; Vanmarcke, H.; Aitkulov, A.; Sadyrov, O.; Savosin, M.; Tolongutov, B.; Mirzachev, M.; Clerc, J.J.; et al. Assessment of radiation exposure in the uranium mining and milling area of Mailuu Suu, Kyrgyzstan. J. Environ. Radioact. 2006, 88, 118-139. [CrossRef]

58. Aleshin, Y.; Torgoev, I. Slope Dynamic Geomorphology of the Mailuu-Suu Area, Aspects of Long-Term Prediction. In Landslide Science for a Safer Geo-Environment; Sassa, K., Ed.; Springer International Publishing: Cham, Switzerland, 2014; pp. 339-343.

59. Torgoev, A. Assessment of Landslide Hazard in the Environmental Hotspot Areas of the Kyrgyz Tien-Shan: Spatial Analysis and Numeric Modelling. Ph.D. Thesis, University of Liège, Liège, Belgium, 2016.

60. Marino, P.; Santonastaso, G.F.; Fan, X.; Greco, R. Prediction of shallow landslides in pyroclastic-covered slopes by coupled modeling of unsaturated and saturated groundwater flow. Landslides 2021, 18, 31-41. [CrossRef]

61. Wang, H.; Liu, S.; Xu, W.; Yan, L.; Qu, X.; Xie, W.C. Numerical investigation on the sliding process and deposit feature of an earthquake-induced landslide: A case study. Landslides 2020, 17, 2671-2682. [CrossRef]

62. Matsuura, S.; Okamoto, T.; Osawa, H.; Shibasaki, T.; Abe, K.; Okada, Y. Fluctuations in the Pore-Water Pressure of a Reactivated Landslide in a Snowy District. In Landslide Science for a Safer Geoenvironment; Springer: Cham, Switzerland, 2014 ; pp. 499-502.

63. Melo, C.; Sharma, S. Seismic coefficients for pseudostatic slope analysis. In Proceedings of the 13th World Conference on Earthquake Engineering, Vancouver, BC, Canada, 1-6 August 2004.

64. Wistuba, M.; Malik, I.; Krzemień, K.; Gorczyca, E.; Sobucki, M.; Wrońska-Wałach, D.; Gawior, D. Can low-magnitude earthquakes act as a triggering factor for landslide activity? Examples from the Western Carpathian Mts, Poland. CATENA 2018, 171, 359-375. [CrossRef]

65. Zhou, C.; Yin, K.; Cao, Y.; Ahmed, B.; Li, Y.; Catani, F.; Pourghasemi, H.R. Landslide susceptibility modeling applying machine learning methods: A case study from Longju in the Three Gorges Reservoir area, China. Comp. Geosci. 2018, 112, 23-37. [CrossRef] 
66. Durand, V.; Mangeney, A.; Haas, F.; Jia, X.; Bonilla, F.; Peltier, A.; Hibert, C.; Ferrazzini, V.; Kowalski, P.; Lauret, F.; et al. On the link between external forcings and slope instabilities in the Piton de la Fournaise Summit Crater, Reunion Island. J. Geophys. Res. Earth Surf. 2018, 123, 2422-2442. [CrossRef]

67. Arino, O.; Ramos Perez, J.J.; Kalogirou, V.; Bontemps, S.; Defourny, P.; Van Bogaert, E. Global Land Cover Map for 2009 (GlobCover 2009). PANGAEA 2012. [CrossRef]

68. Fick, S.E.; Hijmans, R.J. WorldClim 2: New 1-km spatial resolution climate surfaces for global land areas. Int. J. Climatol. 2017, 37, 4302-4315. [CrossRef]

69. Duncan, J.M.; Wright, S.G.; Brandon, T.L. Soil Strength and Slope Stability, 2nd ed.; John Wiley \& Sons. Inc.: Waco, TX, USA, 2014.

70. Pebesma, E.; Bivand, R.; Rowlingson, B.; Gomez-Rubio, V.; Hijmans, R.; Sumner, M.; MacQueen, D.; Lemon, J.; O’Brien, J. Sp: Classes and Methods for Spatial Data. R Package (Version 1.2-1). 2015. Available online: https://cran.r-project.org/web/ packages/sp (accessed on 22 March 2021).

71. R Core Team. R: A Language and Environment for Statistical Computing (Version 3.5.2); R Foundation for Statistical Computing: Vienna, Austria, 2018; Available online: http:/ / www.R-project.org (accessed on 22 March 2021).

72. Oksanen, J.; Blanchet, F.G.; Friendly, M.; Kindt, R.; Legendre, P.; McGlinn, D.; Minchin, P.R.; O’Hara, R.B.; Simpson, G.L.; Solymos, P.; et al. Vegan: Community Ecology Package (Version 2.5-3). 2018. Available online: http://cran.r-project.org/web/packages/ vegan (accessed on 22 March 2021).

73. Breiman, L.; Cutler, A.; Liaw, A.; Wiener, M. RandomForest: Breiman and Cutler's Random Forests for Classification and Regression (Version 4.6-14). 2018. Available online: https:/ / cran.r-project.org/web/packages/randomForest (accessed on 22 March 2021).

74. Krkač, M.; Bernat Gazibara, S.; Arbanas, Ž.; Sečanj, M.; Mihalić Arbanas, S. A comparative study of random forests and multiple linear regression in the prediction of landslide velocity. Landslides 2020, 17, 2515-2531. [CrossRef]

75. Dai, F.C.; Lee, C.F. Frequency-volume relation and prediction of rainfall-induced landslides. Eng. Geol. 2001, 59, 253-266. [CrossRef]

76. Chalkias, C.; Ferentinou, M.; Polykretis, C. GIS-based landslide susceptibility mapping on the Peloponnese Peninsula, Greece. Geosciences 2014, 4, 176-190. [CrossRef]

77. Rosenbaum, L. An Autonomous Wireless Turbidity Sensor Network with On-Site Data Transmission Developed for Distributed Measurements Along Rivers. Master's Thesis, Chemnitz University of Technology, Chemnitz, Germany, 2021.

78. Schneider, P.; Meyer, A.; Li, F. Emergency response planning as a tool to support natural and natech risk management. In Encyclopedia of the UN Sustainable Development Goals; Leal Filho, W., Azul, A.M., Brandli, L., Lange Salvia, A., Özuyar, P.G., Wall, T., Eds.; Springer: Cham, Germany, 2020. 